\title{
Identifying recommended dietary allowances for protein and amino acids: a critique of the 2007 WHO/FAO/UNU report
}

\author{
D. Joe Millward* \\ Division of Nutritional Sciences, Faculty of Health and Medical Sciences, University of Surrey, Guildford GU2 7XH, UK
}

(Submitted 30 August 2011 - Final revision received 14 November 2011 - Accepted 6 January 2012)

\section{Abstract}

The WHO/FAO/UNU (2007) report examines dietary protein and amino acid requirements for all age groups, protein requirements during pregnancy, lactation and catch-up growth in children, the implications of these requirements for developing countries and protein quality evaluation. Requirements were defined as the minimum dietary intake which satisfies the metabolic demand and achieves nitrogen equilibrium and maintenance of the body protein mass, plus the needs for growth in children and pregnancy and lactation in healthy women. Insufficient evidence was identified to enable recommendations for specific health outcomes. A meta analysis of nitrogen balance studies identifies protein requirements for adults $10 \%$ higher than previous values with no influence of gender or age, consistent with a subsequently published comprehensive study. A new factorial model for infants and children, validated on the basis of the adequacy of breast milk protein intakes and involving a lower maintenance requirement value, no provision for saltatory growth and new estimates of protein deposition identifies lower protein requirements than in previous reports. Higher values for adult amino acid requirements, derived from a re-evaluation of nitrogen balance studies and new stable isotope studies, identify some cereal-based diets as being inadequate for lysine. The main outstanding issues relate to the biological implausibility of the very low efficiencies of protein utilisation used in the factorial models for protein requirements for all population groups especially pregnancy when requirements may be overestimated. Also considerable uncertainty remains about the design and interpretation of most of the studies used to identify amino acid requirement values.

\section{Introduction}

Dietary allowances for protein were first published in 1935 by the League of Nations and then by FAO/WHO Expert Committees in $1957^{(1)}, 1965^{(2)}, 1973^{(3)}$ and $1985^{(4)}$. The most recent consultation was published by WHO at the end of $2007^{(5)}$ more than 6 years after the initial meeting in Rome. Defining protein requirements is not an easy task and the recent consultation was particularly difficult with the deaths of 4 key members, Peter Reeds, Bernard Beaufrère, Vernon Young and Peter Furst. Those interested in the process should read Scrimshaw's 1976 analysis $^{(6)}$ of the strengths and weaknesses of the committee approach. Although most previous reports have been largely written by the chairman, the most recent report represents a consensus view reached in some cases against a background of divergent interpretations of the relevant scientific literature. Because of this there are several issues which remain arguably incomplete or unsatisfactory. My purpose here is to summarise the main findings, identifying my own views on their strengths and weakness.

\section{Conceptual framework}

In this new (2007) report dietary protein and amino acid requirements are defined within a generic model based on the metabolic demand, (i.e. the needs of the organism), and the efficiency of dietary protein utilization to meet this demand: thus dietary requirement $=$ metabolic demand/efficiency of utilization. The term metabolic demand is new to this report (although the principle is not), and is determined by the nature and extent of those metabolic pathways that irreversibly consume amino acids and give rise to urinary, faecal and other nitrogenous losses and which includes a small component of net protein synthesis in skin, hair and secretions. Thus although protein synthesis associated with turnover accounts for the largest component of amino acid removal, as shown in Fig. 1 because this is largely met through amino acids deriving from proteolysis which match the amount and pattern required for protein synthesis, it is not a significant part of the organism's net demand. In fact the demand will be dominated by the flow to other pathways which irreversibly consume amino acids in terms of their carbon skeletons or nitrogen. This component is identified in factorial models of requirements as the metabolic basis of maintenance. In addition the protein requirement includes any special needs, which, for this report include the demand for growth in infants and children, pregnancy and lactation. In each case, the dietary requirement to meet these demands is determined by the efficiency of dietary protein utilisation in their provision.

*Corresponding author: D. Joe Millward, email D.Millward@surrey.ac.uk 


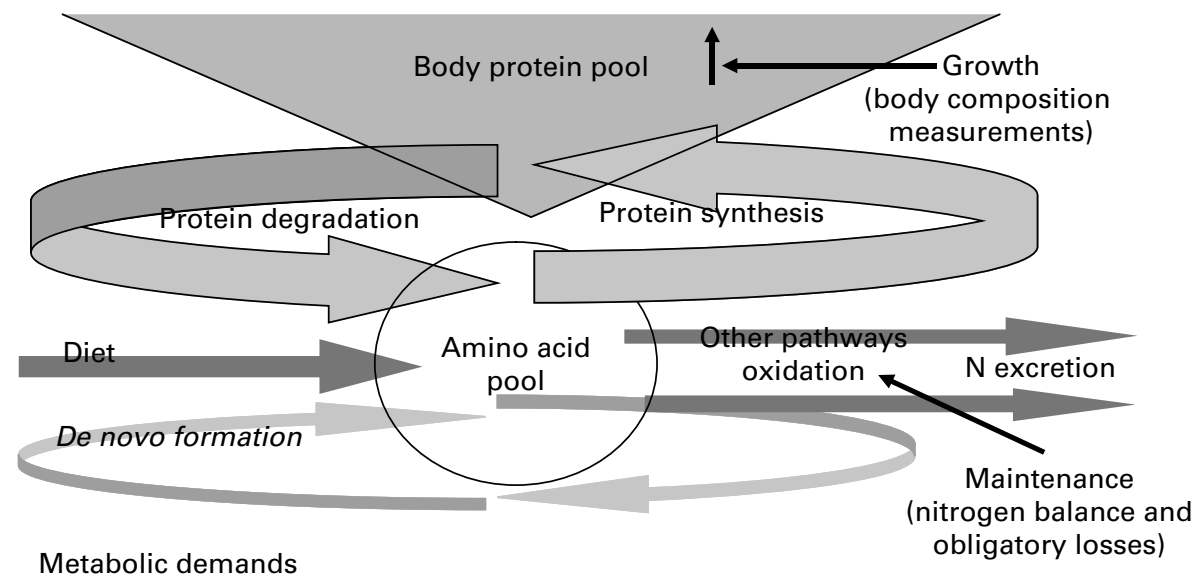

Growth + maintenance

Dietary requirement

Metabolic demand/efficiency of utilisation

Fig. 1. General model for amino acid interchange and for the assessment of the protein requirement.

Within this conceptual framework the minimum protein requirement (MPR) is defined as: the lowest level of dietary protein intake that will balance the losses of nitrogen from the body, and thus maintain the body protein mass, in persons at energy balance with modest levels of physical activity, plus, in children or in pregnant or lactating women, the needs associated with the deposition of tissues or the secretion of milk at rates consistent with good health. The report acknowledges that this definition of the requirement in terms of nitrogen balance does not necessarily identify the optimal intake for health, which is less quantifiable. It is assumed, however, that the body protein mass is maintained at a desirable level.

The new report also considered the important issue of adaptation which has always posed a difficult problem for both the design and interpretation of studies in this area and for which different views have been expressed about its importance. My own view is that the plausibility of most work in the area requires adaptation to be considered and this is discussed further below.

\section{Report findings}

Table 1 is a summary of all protein requirement values identified in the report shown in terms of the method adopted and the components of the requirement values (i.e. the metabolic demand and efficiency of utilisation used to calculate the mean requirement) the coefficient of variation $(\mathrm{cv})$ of the mean requirement and the safe intake calculated as mean $+2 \mathrm{sd}$.

The adult maintenance requirement: mean, safe individual and safe population intakes, safe upper limit

Nitrogen balance (NB) studies have been central to all previous efforts to derive the adult MPR whether directly, by assessing the intake for $\mathrm{N}$ equilibrium ${ }^{(1,5)}$, or indirectly as a source of values used in the factorial method ${ }^{(2,3)}$. The 1985 report $^{(4)}$ examined a limited number of $\mathrm{NB}$ studies in a somewhat arbitrary way deriving values for the average requirement of $0.6 \mathrm{~g} / \mathrm{kg} / \mathrm{d}$ and a safe intake of $0.75 \mathrm{~g} / \mathrm{kg} / \mathrm{d}$. The current report examined essentially the same published data but in a more systematic way utilising a meta analysis/ reanalysis of all published NB studies ${ }^{(7)}$. All studies in which individual balance values were reported at three or more intakes, within a restricted range (from 50 to $200 \mathrm{mg} \mathrm{N} / \mathrm{kg}$ body wt), were reanalysed by linear regression in terms of slopes, intercepts and the intake for N-equilibrium (intercept/slope); in effect a factorial model. No trimming was used so that the data set analysed included individual requirement values ranging from -29 to $+451 \mathrm{mgN} / \mathrm{kg} / \mathrm{d}$ with slopes from -0.27 to 1.26 and intercepts from -122 to $5.87 \mathrm{mgN} / \mathrm{kg} / \mathrm{d}$ : ie. a range of values some of which were biologically not sensible, (slopes negative or $>1$ or with positive intercepts). The median slope (efficiency), intercept (demand), and the requirement (intercept/slope) were identified as $0.47,48.1 \mathrm{mg} \mathrm{N} / \mathrm{kg} / \mathrm{d}$ and $105 \mathrm{mg} \mathrm{N} / \mathrm{kg} / \mathrm{d}$ or $0.66 \mathrm{~g}$ protein $/ \mathrm{kg} / \mathrm{d}$. The demand, indicated from the regression intercept, equivalent to only $0.30 \mathrm{~g} / \mathrm{kg} / \mathrm{d}$, is similar to the values of the obligatory nitrogen loss directly measured in subjects fed a protein free diet.

On the basis of an estimate of true between-individual variation the safe individual intake was identified as $0.83 \mathrm{~g} / \mathrm{kg} / \mathrm{d}$. This is an intake meeting the requirements of $97.5 \%$ of individuals in a population (i.e. the risk of deficiency for any individual at this intake is $\leq 2.5 \%$.). In this report for the first time the safe population intake was identified. It was argued that safe individual values are not appropriate for dealing with population data, although this is a common misuse. This is because the prevalence of deficiency for any mean population intake will vary with the distribution of the intake as well as that of the requirement. In fact when, as is likely, variation in intake is greater than the variation in the requirement, the safe population level will be greater than the safe individual intake and will usually approximate to an 
Table 1. Protein requirements and methodology involved for the various population groups identified in the 2007 report

\begin{tabular}{|c|c|c|c|c|c|c|c|}
\hline Population group & Method & & $\begin{array}{l}\text { Demand g } \\
\text { protein } / \mathrm{kg} / \mathrm{d}\end{array}$ & Efficiency & $\begin{array}{l}\text { Mean requirement } \\
\mathrm{g} / \mathrm{kg} / \mathrm{d}\end{array}$ & $\mathrm{cv}$ & Safe level \\
\hline $\begin{array}{l}\text { Adults all ages, men } \\
\text { and women }\end{array}$ & $\begin{array}{l}\text { N-balance (meta analysis): linear regression of } \\
\text { individual multilevel studies: } n=235: \\
\text { demand = median intercept, efficiency } \\
\text { = median slope. }\end{array}$ & & $0.30(-48.1 \mathrm{mgN} / \mathrm{kg})$ & 0.47 & 0.654 & $» 12 \%$ & 0.83 \\
\hline \multirow[t]{3}{*}{ Pregnant women } & $\begin{array}{l}\text { Factorial: demand from increased maintenance } \\
\text { costs associated with increased body weight } \\
\text { at end of each trimester }(0 \cdot 5,3 \cdot 2,7 \cdot 3 \mathrm{~g} / \mathrm{kg} / \mathrm{d}) \text {, } \\
\text { plus mean protein deposition estimated from } \\
\text { TBK accretion in normal healthy pregnant } \\
\text { women gaining } 13 \cdot 8 \mathrm{~kg},(0,1 \cdot 9,7 \cdot 4 \mathrm{~g} / \mathrm{kg} / \mathrm{d}) \text {. } \\
\text { Efficiency from } \mathrm{N} \text { balance studies in primipar- } \\
\text { ous teenagers }\end{array}$ & $\begin{array}{l}\text { 1st } \\
\text { 2nd } \\
\text { 3rd }\end{array}$ & $0.5+0$ & & 0.5 & $12 \%$ & 0.7 \\
\hline & & & $3.2+1 \cdot 9$ & 0.42 (deposition) & $7 \cdot 7$ & $12 \%$ & 9.6 \\
\hline & & & $7 \cdot 3+7 \cdot 4$ & 0.42 (deposition) & 24.9 & $12 \%$ & $31 \cdot 2$ \\
\hline \multirow[t]{2}{*}{ Lactating women } & $\begin{array}{l}\text { Factorial: demand from mean milk protein out- } \\
\text { put (Total } \mathrm{N} \text { les NPN N), by well-nourished } \\
\text { women exclusively breastfeeding (first } \\
6 \text { months postpartum) and partially breast- } \\
\text { feeding (second } 6 \text { months). Efficiency from N } \\
\text { balance studies in non-lactating adults. }\end{array}$ & $0-6 \mathrm{mo}$ & $6 \cdot 79-7 \cdot 60$ & 0.47 & $14 \cdot 3-16 \cdot 2$ & $12 \%$ & $17 \cdot 9-20 \cdot 2$ \\
\hline & & $6-12 \mathrm{mo}$ & 4.69 & 0.47 & 10 & $12 \%$ & $12 \cdot 5$ \\
\hline Infants (0-6mo) & $\begin{array}{l}\text { Factorial: maintenance plus growth: mainten- } \\
\text { ance from N-balance studies with studies } \\
\text { with milk and egg }(0.58 \mathrm{~g} \text { protein } / \mathrm{kg} / \mathrm{d}) \text { plus } \\
\text { deposition costs from TBK measurements. }\end{array}$ & & $0.385+$ deposition & $\begin{array}{l}0.66 \text { (maintenance } \\
\text { and growth) }\end{array}$ & $1.41-0.98$ & $8-13 \%$ & $1 \cdot 77-1 \cdot 14$ \\
\hline Children (6mo-18y) & $\begin{array}{l}\text { Factorial: maintenance plus growth: adult main- } \\
\text { tenance value }((0.66 \mathrm{~g} \text { protein } / \mathrm{kg} \text { per day }) \\
\text { plus growth costs from TBK studies of pro- } \\
\text { tein gain adjusted with efficiency value from } \\
\text { all } N \text { balance studies on children } 6 \text { mo to } 12 \mathrm{y} \\
(0.58)\end{array}$ & & $0 \cdot 30+$ deposition & $\begin{array}{c}0.47 \text { (maintenance) } \\
0.58 \text { (growth) }\end{array}$ & $\begin{array}{l}1 \cdot 12-0.66(\mathrm{f}) \\
1 \cdot 12-0 \cdot 69(\mathrm{~m})\end{array}$ & $8 \cdot 9-12 \%$ & $\begin{array}{l}1.31-0.82(\mathrm{f}) \\
1.31-0.85(\mathrm{~m})\end{array}$ \\
\hline $\begin{array}{l}\text { Catch-up growth in } \\
\text { children at } 5 \mathrm{~g} / \mathrm{kg} / \mathrm{d}\end{array}$ & $\begin{array}{l}\text { As for normal children plus growth costs calcu- } \\
\text { lated assuming protein contents of weight } \\
\text { gain as } 14 \% \text { (typical) or } 9.6 \% \text { (high fat) }\end{array}$ & & $0.30+$ deposition & $\begin{array}{c}0.47 \text { (maintenance) } \\
0.70 \text { (growth) }\end{array}$ & $\begin{array}{l}1.82 \text {, typical } 1.5 \text { high } \\
\text { fat P:E ratio } 6.9 \% \\
\text { typical } 5.2 \% \text { high fat }\end{array}$ & - & - \\
\hline $\begin{array}{l}\text { Catch-up growth in } \\
\text { children at } \\
20 \mathrm{~g} / \mathrm{kg} / \mathrm{d}\end{array}$ & $\begin{array}{l}\text { As for normal children plus growth costs calcu- } \\
\text { lated assuming protein contents of weight } \\
\text { gain as } 14 \% \text { (typical) or } 9.6 \% \text { (high fat) }\end{array}$ & & 0.30 + deposition & $\begin{array}{l}0.47 \text { (maintenance) } \\
0.70 \text { (growth) }\end{array}$ & $\begin{array}{l}4.82 \text { typical } 3.6 \text { high } \\
\text { fat P:E ratio } 11.5 \% \\
\text { typical } 6.9 \% \text { high fat }\end{array}$ & - & - \\
\hline
\end{tabular}


intake that is somewhat greater than the average requirement plus $2 \mathrm{SD}$ of the intake. The report also examines the safe upper limit which in the past has somewhat arbitrarily been set at $1.5 \mathrm{~g} / \mathrm{kg} / \mathrm{d}$, (i.e. twice the safe individual allowance). Average protein intakes of populations consuming the mixed diets of developed countries will usually be considerably in excess of recommended intakes, especially for those with high levels of energy expenditure and those who consume more than average meat intakes. Indeed some consume protein supplements resulting in intakes of 3-4 times the recommended intake with little evidence of harm (or benefit). Having reviewed current knowledge of the relationship between protein intake and health, the report was unable to give clear recommendations about either optimal intakes for long-term health or to define a safe upper limit. It did conclude however that it is unlikely that intakes of twice the safe level are associated with any risk and also advised caution to those contemplating the very high intakes of 3-4 times the safe intake which approach the tolerable upper limit and cannot be assumed to be risk-free. The overall distribution of individual values from the meta analysis and the values for the average, safe individual and population intake are shown in Fig. 2.

\section{Protein requirements of infants and children}

All reports to date have focussed on a detailed consideration of the protein intakes of the breast-fed infant. The new report faced a challenge from a member of the 1985 consultation that this committee had overestimated the MPR, because of an error ${ }^{(8)}$. This was that the average intake of breast milk of infants of healthy mothers should be similar to and could therefore guide the value of the average protein requirement. As a result a higher value for maintenance was used and an additional $50 \%$ was added to the overall value to cover day to day variation in growth. On this basis an average requirement had been calculated which was similar to the average intake from breast milk. This meant that the safe allowance was much higher than breast milk intakes. When the adequacy of breast milk to provide these requirement intakes was calculated in terms of the prevalence of deficiency in breast fed infants, breast milk was identified as grossly inadequate ${ }^{(8)}$. In a detailed analysis Dewey, with Beaton and others ${ }^{(9)}$ had shown that if average intakes of protein from breast milk were adequate for most infants (i.e. associated with very low prevalence rates of deficiency), then compared with such intakes, the safe allowance should be somewhat lower and the mean requirement much lower. In the new report this view was accepted and a factorial model for the requirement of infants and children from 6 months to $18 \mathrm{y}$ was adopted which identified lower values, by using a lower maintenance value, (derived from NB studies in children with egg or milk), and removing the extra $50 \%$ for day to day variability. It had been argued $^{(9)}$ that because the maintenance requirement was probably generous on those days when growth was particularly rapid, some of the maintenance allowance could be diverted to growth. Although requirement values were not specifically defined for infants $<6$ months, (on the basis that these should be breast fed), the factorial model was also applied to this age group and a table of safe intakes calculated, so that it could be validated by comparing the derived values for the MPR with breast milk protein intakes.

Because new information had been published on the body composition of infants and older children the rate of protein accretion during normal growth could be identified enabling a factorial model based on maintenance and growth to be defined. As shown in Table 1 maintenance for infants $<6$ months was derived from a limited number of NB studies in infants and children, whereas for older infants $>6$ months and children the adult maintenance value was adopted. The efficiencies assumed in these factorial models for maintenance and growth derived from the slopes of the NB studies, i.e. 0.66 for maintenance and growth in infants, and 0.58 for growth in older infants and children. In the latter case where the adult maintenance value was assumed, the implied efficiency for meeting the obligatory demands is 0.47 as discussed above.

Validation of the infant's model against breast milk intakes is no easy task because of the need to consider the extent of utilisation by the infant of the considerable non protein nitrogen

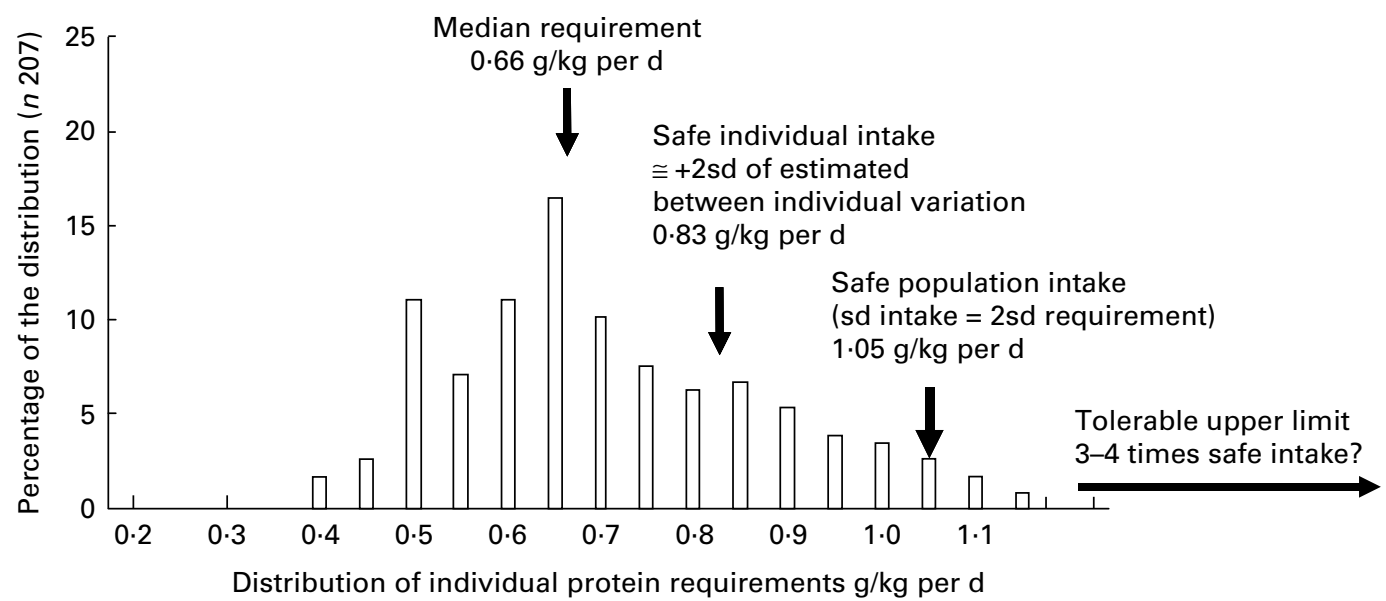

Fig. 2. Distribution of the individual protein requirements identified in the meta analysis of nitrogen balance studies. 
in breast milk. Nevertheless this was done and the values derived from the model, considerably lower than those in the 1985 report, were now considered to be, for the most part, satisfactory. Thus when judged against these new values for the safe MPR, average protein intakes from breast milk were judged adequate. In fact the new requirement values in the latter months of breast feedings were identified as still somewhat high, although not markedly so. However because the main use of these requirement values is to inform on the composition of formula feeds which might not be utilised as well as breast milk, this was judged as acceptable.

\section{Protein requirements for catch up growth}

Factorial calculations of the requirements for weight gain in terms of absolute values of protein and the protein:energy ratio of the feed are relatively straightforward, but they do require assumptions to be made about the composition of the weight gain (lean or adipose tissue), the magnitude of the maintenance values for protein and energy, the efficiency of both dietary protein and energy utilization, and the efficiency of net protein and fat deposition. The importance of providing sufficient energy was stressed since very early studies attempting to refeed malnourished children with high protein feeds were unsuccessful because of a lack of sufficient energy. In the report, values were calculated on the basis of both a typical composition of weight gain i.e. 73:27 lean:fat: $14 \%$ protein, $27 \%$ fat, and a high fat weight gain: i.e. 50:50 lean:fat 9.6\% protein, 50\% fat. The report showed that as weight gain increased from 1 to $20 \mathrm{~g} / \mathrm{kg} / \mathrm{d}$, energy requirements and the protein energy (P:E) ratio for a typical composition, increased from 89 to $167 \mathrm{kcal} / \mathrm{kg} / \mathrm{d}$ and from 4.6 to $11.5 \% \mathrm{P}: \mathrm{E}$ and for a high fat weight gain, from 91 to $205 \mathrm{kcal} / \mathrm{kg} / \mathrm{d}$ and from 4.2 to $6.9 \% \mathrm{P}: \mathrm{E}$. The importance of these figures is that they demonstrate that the most rapid growth rates which children are likely to achieve can be mediated with feeds in which the protein content is $<12 \%$ energy, as long as the child is able to consume sufficient of the feed. To do this feeds can be made calorie dense with either fat or sugar which means the feeds are less satiating than when the protein concentration is too high. Growth studies with malnourished children have shown that such feeds do allow growth rates at the expected level ${ }^{(10)}$.

\section{Protein requirements for pregnancy and lactation}

In this new report whereas the MPR for infants and children is lower than in the 1985 report, the values for pregnancy are very much higher, a three fold increase in the last trimester. The 1985 Consultation $^{(4)}$ calculated safe levels of additional protein of $1.2,6 \cdot 1$ and $10 \cdot 7 \mathrm{~g}$ /day in the first, second and third trimesters, respectively, but argued for a single average value of $6 \mathrm{~g}$ /day to be added to the non-pregnant allowance throughout pregnancy. In contrast the new values are 0.7 , 9.6 and $31.2 \mathrm{~g} / \mathrm{kg} / \mathrm{d}$ (Table 1). Both estimates are based on similar values for total protein deposition in the products of conception $(711 \mathrm{~g}$ and $686 \mathrm{~g}$ ) but there are two major changes in the new report. Firstly the dietary efficiency value used to adjust the predicted deposition rate, derived from NB studies is now 0.42 , the lowest value of those used anywhere in the report, compared with $70 \%$ in the 1985 report which had rejected such low values. Secondly the increased demand also includes increased maintenance costs due to maternal weight gain which overall are calculated to be greater than protein deposition.

Because of this increase in requirements compared with the 1985 report and in the light of reports indicating risk to mothers given very high protein supplements (discussed further below), the report recommends that the higher intake during pregnancy should consist of normal food, rather than commercially prepared high protein supplements.

For lactation, recommendations are made for wellnourished women exclusively breastfeeding for 6 months and partially breastfeeding after this. Although the efficiency factor used to calculate the dietary intake to provide for breast milk protein was lower in the new report (47\% i.e. the same as that indicated by the adult NB studies, compared with $70 \%$ in the 1985 report) protein secreted in breast milk was judged to be slightly lower so that the values shown in Table 1 are similar to those in the previous report.

\section{Biological plausibility of protein requirement values}

The question can be asked, is this the best we can do? Will this be the last word as far as defining protein requirements is concerned? In fact it is highly unlikely that many more multilevel NB studies will be published, especially on children, although one post-report study has addressed the issue of ageing and gender in relation to the adult MPR, issues not adequately addressed in the meta analysis. Overall this new study ${ }^{(11)}$ which examined the MPR of young and older adult men and women by means of linear regression to identify the equilibrium intake (intercept/slope), indicated similar values as observed in the meta analysis, a median requirement value of 0.62 with no age and gender effects.

In my view the most important outstanding issue is the lack of biological plausibility of the adult requirement value and the efficiency values used in the factorial models for infants, children, and pregnancy. The adult demand, the obligatory nitrogen loss (ONL), all nitrogen losses measured after 1-2 weeks on a protein free diet equivalent to about $0.30 \mathrm{~g}$ protein $/ \mathrm{kg} / \mathrm{d}$, is well documented, and for high quality animal protein, in theory, only digestibility, at about $95 \%$, should limit protein utilisation. The slope of an NB curve is in theory a measure of net protein utilisation, NPU, the product of digestibility and biological value itself related to amino acid score. Because the data set used for the report derives from studies with mainly animal proteins this value might be expected to give a value approaching 1 . In fact $90 \%$ of the studies had slope values below 0.77 . In other words hardly any of the 237 studies resulted in biologically plausible values. It is important therefore to closely examine both the design and analysis of nitrogen balance studies to try and explain this lack of plausibility. 


\section{Limitations in design and analysis of nitrogen balance} studies

\section{a: Variability and potential influences on outcomes}

The NB approach is the only available method with a conceptually straightforward endpoint (ie, nitrogen equilibrium). Although some reject the NB approach as fatally flawed, to date no alternative approach has been identified and in my view if interpreted with care it does provide important information. The main limitations of the NB approach have been well described ${ }^{(12-14)}$ and were thoroughly reviewed in the new report. It suffers from a lack of precision, the possibility of systematic error and logistical problems: i.e. ensuring energy balance (see ${ }^{15}$ ) and sufficient time for adaptation to each protein intake. It is the case that during any particular measurement period, balance may be more or less positive than might be expected and this is illustrated by the results of the meta analysis shown in Fig. 3. There are numerous instances of both positive and negative nitrogen balances for the range of protein intakes from 0.4 to $0.8 \mathrm{~g} / \mathrm{kg} / \mathrm{d}$.

In trying to account for the lack of plausibility of the balance data the first issue to examine is its marked variability which is much greater than that implied by the safe intake. In fact the $97.5^{\text {th }}$ centile of the overall data set, $(n=235, \approx 1.36 \mathrm{~g} / \mathrm{kg} / \mathrm{d})$, is $64 \%$ greater than $0.83 \mathrm{~g} / \mathrm{kg} / \mathrm{d}$. After trimming for impossible values, the slopes varied between 0.03 to 1 and the intercepts from $-120 \mathrm{mgN} / \mathrm{kg} / \mathrm{d}$ to $-6.8 \mathrm{mgN} / \mathrm{kg} / \mathrm{d}$. Slopes and intercepts were highly inversely correlated, $\left(\mathrm{R}^{2}=0.67\right)$, as might be expected (steeper slopes giving more negative intercepts) and neither predicted the requirement, (intercept/slope) more than the other (i.e. on their own the slopes or intercepts explained only $6 \cdot 6-8.9 \%$ of the variance of the estimated requirement). This ranged from 0.34 to $2.8 \mathrm{~g}$ protein $/ \mathrm{kg} / \mathrm{d}$ and although values tended to increase as average study $\mathrm{N}$ intake increased, this variable explained only $8 \%$ of the variance in requirement. This large overall variability means that

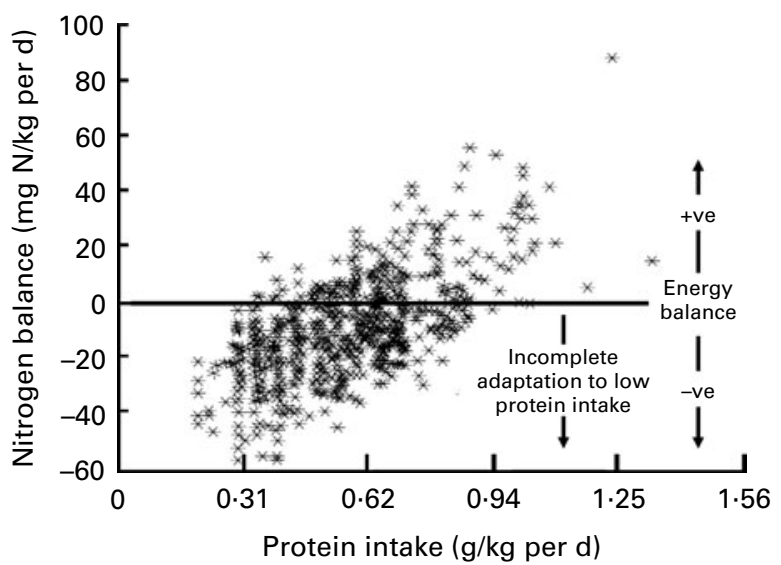

Fig. 3. Study design factors influencing $\mathrm{N}$ balance. Individual nitrogen balance points of subjects included in the meta analysis used to identify the current protein requirement. Figure redrawn from reference 5. Energy intakes above or below energy expenditure rates will increase or decrease nitrogen balance. Incomplete adaptation to the low protein intakes fed in balance trials will decrease nitrogen balance. only by markedly reducing the total variance by $80 \%$, through a statistical partitioning calculation to give the "true" between individual variation, could a sensible safe intake of $0.83 \mathrm{~g} / \mathrm{kg} / \mathrm{d}$ be arrived at. Clearly while the median protein requirement value of $0.65 \mathrm{~g} / \mathrm{kg} / \mathrm{d}$ is only $10 \%$ higher than previous values, a safe intake of $1.36 \mathrm{~g} / \mathrm{kg} / \mathrm{d}$ would be quite out of the question and a partitioning of variance as reported would seem appropriate.

In terms of ensuring zero energy balance this is well nigh impossible so that some degree of weight loss or gain with associated negative or positive $\mathrm{NB}$ is inevitable and data demonstrating this have been reported by several authors ${ }^{(16,17)}$. Furthermore, because individual rates of energy expenditure and requirement vary markedly, and because NB is very sensitive to energy balance ${ }^{(7)}$, within most studies there is likely to be considerable individual variability in the extent of energy imbalance which will contribute to individual variability in NB. In fact my calculations of the likely error of $\pm 10 \%$ in estimating BMR and consequent energy needs $\left(4.5 \mathrm{kcal} / \mathrm{kg} / \mathrm{d},{ }^{15}\right)$, show it to be equivalent to a variability in requirement of about $\pm 10 \mathrm{mg} / \mathrm{kg} / \mathrm{d}$ which is about one-third of the total between individual variance or about $85 \%$ of the estimated true between individual variance. In practical terms in multilevel NB studies aimed at measuring protein or amino acid requirements, actual rates of energy expenditure and consequent energy requirements are never measured, instead body weight monitoring is the usual measure of energy sufficiency during the study. In this case how well energy balance maintenance was maintained would depend on the vigilance of body weight monitoring in what are usually short-term studies. An overestimate of $4.5 \mathrm{kcal} / \mathrm{kg} / \mathrm{d}$ could result in $0.5-1 \mathrm{~g}$ of tissue gain $/ \mathrm{kg} / \mathrm{d}$ equivalent to $0 \cdot 25-0.5 \mathrm{~kg}$ of weight gain per wk for a $70-\mathrm{kg}$ adult. Clearly this would be substantial weight gain if maintained but might be considered within the normal range in a short-term study. According to some authors, even if energy intakes are constant, markedly increasing or decreasing protein intakes compared with habitual levels results in gains or losses in body weight and associated positive or negative nitrogen balance $^{(16)}$. Thus one explanation of the considerable variability in the balance data is lack of energy balance although the extent of this influence cannot be quantified.

A second explanation of the variability in the balance data is a variable extent of adaptation of the metabolic demand for amino acids to the test protein intakes during these short term balances. Incomplete adaptation would result in an underestimation of the intake for equilibrium. This has been observed and commented on by many investigators although some do not accept that it is important ${ }^{(7)}$. During studies on older women ${ }^{(18)}$ the authors reported improving balances after 14-17 days compared with 7-10 days: i.e., on the lowest intake $(0.53 \pm 0.02 \mathrm{~g}$ protein $/ \mathrm{kg} / \mathrm{d})$, net nitrogen balances fell from $-14.5 \pm 3 \cdot 1$ to $-0 \cdot 1 \pm 2.7 \mathrm{mg} \mathrm{N} / \mathrm{kg}$ perd i.e. nitrogen equilibrium. This is consistent with long term 14 week studies by this group ${ }^{(19)}$. Balance studies on young African men ${ }^{(20)}$ showed significantly different balances on a low intake of $0.35 \mathrm{~g}$ protein $/ \mathrm{g} / \mathrm{d}$, according to the sequence of dietary intakes fed. Thus when this low intake was fed 
with a descending dietary design, (i.e. as the last diet in the study so that balance was measured after 50 days during which time the diet had been sequentially reducing, with much longer for adaptation to occur), balance was less negative. When it was fed with an ascending design (i.e. as the first diet in the series so that balance was measured 10 days after the habitual diet), balance was much more negative. In long-term nutritional studies with mental patients who were weight stable on a low protein diet $(0.65 \mathrm{~g} / \mathrm{kg} / \mathrm{d})$ for 36 weeks $^{(21)}$, urinary nitrogen continued to fall after the marked initial fall at 2 weeks to levels which were $18 \%$ lower at 36 weeks and the investigators commented "one does not achieve a steady state of urinary nitrogen excretion until at least three months after a major decrease has been made in the level of protein intake; this time factor being dependent on previous levels of protein intake." Finally subjects who were switched from a high to a moderate protein intake took more than a month to achieve nitrogen equilibrium $^{(16)}$. Thus variable adaptation to the test intakes is another explanation of the variability in the balance data. However, as with potential energy imbalance, the extent of this influence cannot be quantified.

\section{b. Unexplained positive nitrogen balances}

Because human adults do not grow, net protein deposition should only occur during weight gain related to obesity development. This means that the aim of nitrogen balance studies is to study utilisation of increasing protein intakes in the sub-maintenance range allowing the measurement of the efficiency of dietary protein to replace body proteins in providing for the obligatory losses. This is illustrated in Fig. 4 which combines data from the recent studies of the protein requirement of young and older adults ${ }^{(11)}$ and studies involving a large number of young MIT male students fed varying levels of egg protein ${ }^{(22)}$. As shown, the negative balance associated with very low protein intakes, reduces with increasing dietary protein intakes with a curvilinear response as equilibrium is achieved (at intakes above $0.3 \mathrm{~g}$ protein $/ \mathrm{kg} / \mathrm{d}$ ) Ideally, once equilibrium is achieved, balance should not markedly deviate from zero with any further increase in protein intakes, since adults at energy balance maintaining body weight have very limited capacity to gain body $\mathrm{N}$ through an increase in lean tissue. This is evident by the wide range of protein intakes within weight stable adult populations. Both studies shown in Fig. 4 were performed by careful investigators but differ in that the recent studies were performed at intakes $\geq$ the requirement and the subjects exhibited increasing marked positive $\mathrm{N}$ balances with increasing intakes. According to the investigators it is doubtful that lean tissue accretion could account for these positive nitrogen balances given that weight change during the last week of each 18 day dietary period was small $(<1 \%)$ at least for all subjects in all three trials considered together. In fact the mean positive balance of $30 \mathrm{mg} / \mathrm{kg} / \mathrm{d}$ observed on the highest intake is equivalent to a gain of about $1.2 \mathrm{~kg}$ of FFM over the 18 day study. Such a weight gain is easily identified and was not reported to have occurred, the authors reporting that individually, each subject's mean body weight during the balance period (days 14-17) differed by $<1 \%$ from that during the previous week.

This phenomenon of apparent nitrogen accretion is a feature of many balance studies at supra-maintenance intakes included in the meta analysis used in the new report (Fig. 3). What this means is that although both studies shown in Fig. 4 indicate a similar intake for equilibrium $\mathrm{N}$ (ie the protein requirement), it is by no means clear in the recent study what the balance points and the slope represent if not a net gain of body nitrogen. Although systematic errors associated with the overestimation of intake and underestimation of

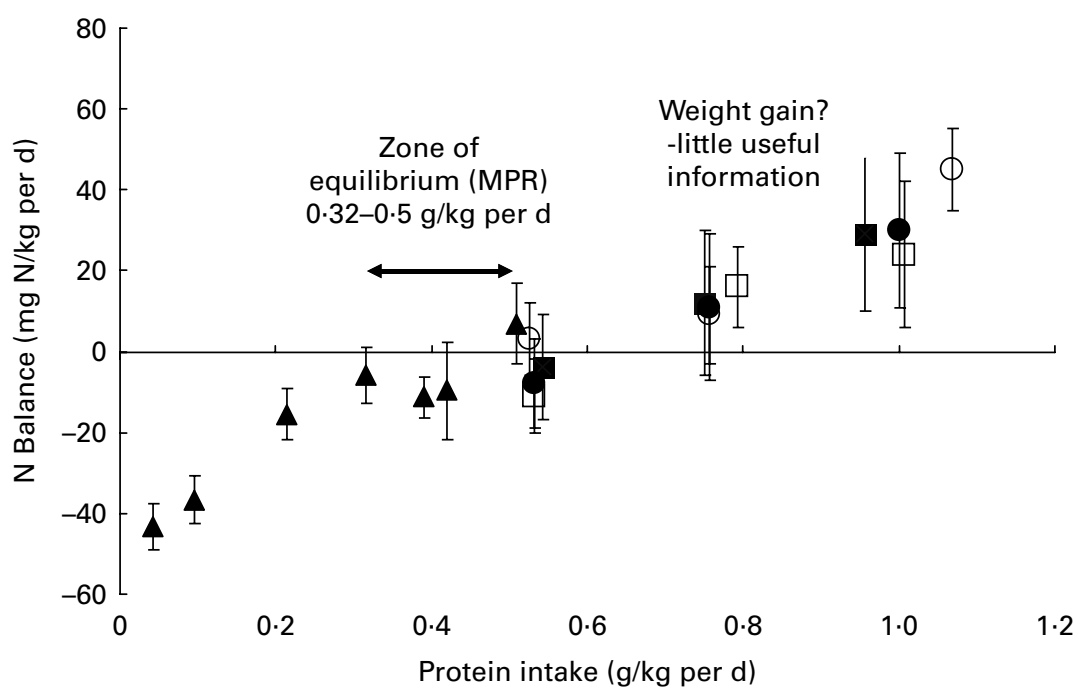

Fig. 4. A pragmatic approach to the analysis of nitrogen balance trials. Values from studies on young men with egg (22) (filled triangles), or on young and elderly men ${ }^{(11)}$ (filled and empty squares) or young and elderly women (filled and empty circles) fed egg and dairy based diets. Instead of adopting the traditional approach of linear or curvilinear analytical models, a pragmatic approach can be used. This would indicate a minimum protein requirement in the range of $0.3-0.5 \mathrm{~g} / \mathrm{kg}$ per $\mathrm{d}$. 
losses are one explanation of an overestimation of balance, it is unlikely that this would be observed by so many investigators. This suggests that there is an unmeasured route of nitrogen loss such as ammonia in the breath, or nitrogen gas produced in the colon as discussed by Rand et al. ${ }^{(7)}$ although their identification in sufficient amounts has to date proved elusive. In fact whilst these authors comment that elimination of molecular nitrogen is a possibility, they are referring to activation of such a pathway with very high protein intakes, having argued that in many long-term studies in healthy adults receiving $0.8 \mathrm{gNkg}^{-1} \mathrm{~d}^{-1}$ balances were not significantly different from zero ${ }^{(17,23)}$. Importantly, if such losses occur at all, in the absence of any information on the shape of the dose response curve of such losses to increasing protein intakes, it is quite impossible to devise an appropriate correction strategy. It may be that unmeasured $\mathrm{N}$ losses are less likely to occur at sub-maintenance intakes if they reflect colonic denitrification of urea, because blood urea levels are very low at low protein intakes with less urea likely to enter the colon. If this is the case then balance studies at submaintenance protein intakes as in Fig. 4 can be assumed to be more reliable.

\section{c. Analysis of $\mathrm{N}$ balance data}

The data shown in Fig. 4 raise a question about the analysis of the balance data. If the approach is to construct a balance curve through all available data then with only 3-4 balance points, linear regression is the only practical approach and has been widely used. However it could be argued that a more pragmatic approach to the interpretation should be taken. For example for the data shown in Fig. 4, the young men B studies could be interpreted as showing the balance curve to be steep and linear up to intakes of $0.32 \mathrm{~g} / \mathrm{kg} / \mathrm{d}$ (slope $=0.89$ ) above which balance fluctuates below or above equilibrium up to the maximum amount fed $0.5 \mathrm{~g} / \mathrm{kg} / \mathrm{d}$. This would indicate a requirement $>0.32$ and $<0.5 \mathrm{~g} / \mathrm{kg} / \mathrm{d}$. In fact a quadratic analysis, as in the original report, indicates a value of $0.46 \mathrm{~g} / \mathrm{kg} / \mathrm{d}$ as the equilibrium intake, but such an analysis is only possible because of the 7 balance points which resulted from combining data from four studies. Taking the initial steep slope as the measure of the efficiency of utilisation this indicates a value of 0.89 which is a biologically sensible value for the efficiency of egg protein utilisation. For the more recent studies shown in Fig. 4 it appears that all subjects are at equilibrium on the lowest intake $(0.53 \mathrm{~g}$ protein $/ \mathrm{kg} / \mathrm{d})$ indicating a requirement $\leq 0.53 \mathrm{~g}$ protein $/ \mathrm{kg} / \mathrm{d}$. However no further useful information is extractable from the positive balances.

It is interesting to note that in the 1973 report, whilst NB studies were examined, the shallow slope at equilibrium intakes was noted and rather than use these balance studies the MPR was derived by the factorial method utilising the ONL (for which good experimental data had been published) to which $30 \%$ was added for "inefficiency." On this basis given that the $30 \%$ addition was used on the basis of a $70 \%$ efficiency of utilisation assumed at the time, the correct calculation, ONL $/ 0 \cdot 7$, would give $0 \cdot 43 \mathrm{~g} / \mathrm{kg} / \mathrm{d}$. The report then identified a safe allowance of $0.57 \mathrm{~g} / \mathrm{kg} / \mathrm{d}$ which was lower than the 1965 report $(0.71 \mathrm{~g} / \mathrm{kg} / \mathrm{d})$. This caused an outcry by some who said that it was a major blunder, and that the additional value of $30 \%$ for "inefficiency" was far too low (although there was never any evidence presented to support such a view). Against this background the 1985 report increased the safe requirement to $0 \cdot 75$, a value not markedly different to that in the most recent report.

\section{An explanation of the apparent low efficiency of dietary protein utilisation: the adaptive metabolic demand}

As far as the potential problems considered so far it is clear that although energy imbalance and incomplete adaptation can account for much of the variation in nitrogen equilibrium, it is by no means clear that they can account for the fact that so few individual balance studies indicate plausible efficiencies of protein utilisation. In fact only by reconsidering the traditional metabolic model can an explanation be identified.

Millward \& Rivers ${ }^{(24)}$ predicted, on mainly theoretical grounds, that amino acid requirements are best described by a model which includes adaptive changes in amino acid oxidation which influence $\mathrm{N}$ losses and result in an apparent inefficiency of utilisation. Since that time however we have reported a series of ${ }^{13} \mathrm{C}$ leucine balance studies that confirm the phenomenon of adaptive oxidative losses of amino acids $^{(13)}$ and we have formalized the concept into an adaptive metabolic demands model ${ }^{(25)}$. This provides a framework for the interpretation of $\mathrm{N}$ balance data. The model identifies metabolic demands for amino acids as comprising a small fixed component and a variable adaptive component, which is relatively insensitive to acute food or protein intake but which changes slowly with a sustained change in intake, enabling $\mathrm{N}$ equilibrium to be achieved at the new intake level when adaptation is complete. Thus with this model the protein requirement can be defined as minimum (MPR) and nominal (NPR) values. The MPR is the same as that in the traditional model, the lowest protein intake allowing maintenance of body composition after complete adaptation. The magnitude of this is currently unknown but likely to be between 0.4 and $0.5 \mathrm{~g} / \mathrm{kg} / \mathrm{d}$, at the lower end of the reported distribution of requirements assessed by NB studies. This is below the intake of subjects consuming mixed diets or diets based on cereals or most starchy roots apart from some very low protein staples such as Ethiopian banana (Ensete), plantain and cassava. The NPR is the intake which allows balance on the subject's habitual diet. Clearly these two requirement definitions make the evaluation of the prevalence of protein deficiency (intake $<$ requirement) problematic. In contrast to the current model, for fully adapted individuals, risk of deficiency (i.e. negative $\mathrm{N}$ balance after complete adaptation) will only start to increase when intakes fall below the range of the true minimum requirements. At intakes above this, deficiency is only likely as a short-term response to a change to a lower intake within the adaptive range. Thus for adults satisfying energy needs on most mixed human diets, intakes will be within the adaptive range, and nitrogen 
equilibrium ceases to be a useful indicator of nutritional adequacy of protein.

The adaptive demands model explains the implausible low efficiency of protein utilisation in NB studies and it allows protein utilisation to be measured in acute studies. Thus the slope assay of NPU equates the slope of the N-balance curve with protein utilization (NPU). This assumes the metabolic demand is constant and equal to the zero intake intercept (the ONL). However as shown in Fig. 5 with an adaptive metabolic demands model, the actual metabolic demands indicated by instantaneous post-absorptive losses will increase with intake. Thus the $\mathrm{N}$ balance curve will underestimate the efficiency of utilisation and the true efficiency will only be indicated when the slope is calculated taking the actual demand into account. This new model also allows post-prandial protein utilisation (PPU) to be measured during the fastingfeeding transition in acute ${ }^{13} \mathrm{C}$ leucine balance studies ${ }^{(26)}$. This indicates the actual efficiency of protein utilisation and such studies with different dietary protein sources allows their protein quality to be assessed at least with highly digestible protein sources. Examples of such studies are shown in Table 2. It is clear that for adult men and women of various age groups examined on their habitual diets or after 2 week periods of adaptation to high or low protein intakes, milk or egg proteins are utilised with near perfect efficiency. Whilst lysine-limited wheat protein is less well utilised as would be

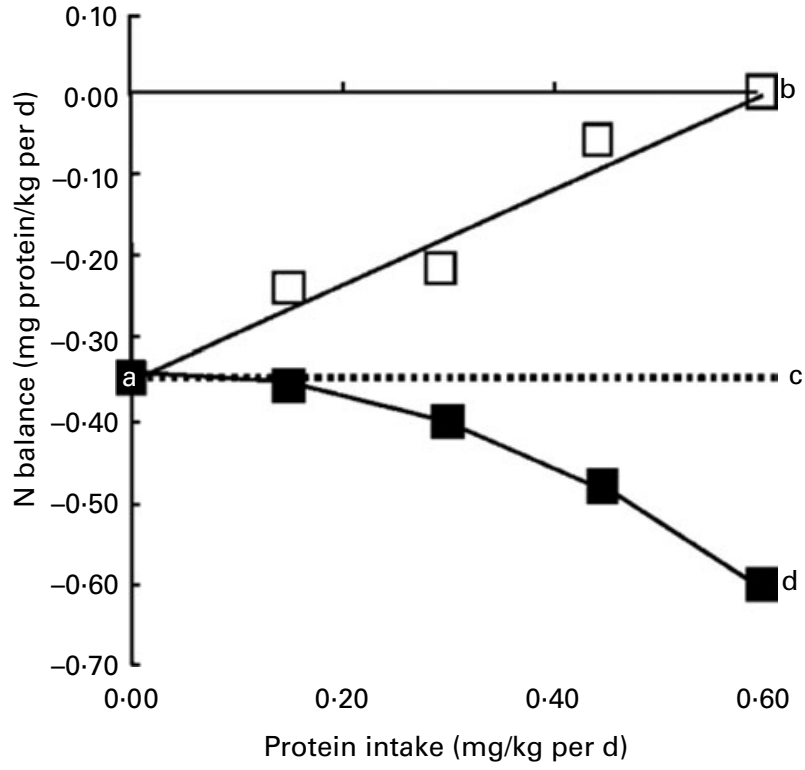

Fig. 5. Actual and assumed values for the metabolic demand (MD) in multilevel nitrogen balance assays of net protein utilization (NPU). Observed nitrogen balance ( $\square$ ), actual metabolic demand (MD) at each intake (ם), assumed MD at each intake (......). The slope assay of NPU equates the slope of the nitrogen balance curve (b-c)/(c-a) with NPU. This assumes that the MD is constant and equal to the zero intake intercept (the obligatory nitrogen loss). However, with an adaptive MD model, the actual MD and instantaneous post-absorptive losses will increase with intake. Thus, the nitrogen balance curve will underestimate the efficiency of utilization and the true efficiency will be indicated by $(b-d) /(c-a)$. The magnitude of the MD and the consequent shape of the balance curve has been arbitrarily drawn assuming an adaptive MD that would result in an apparent overall MD equivalent to $0.60 \mathrm{~g}$ protein expected, the actual efficiency is somewhat higher than would be expected, possibly through recycling of lysine liberated from tissue protein during the catabolic post-absorptive state. Similar results are reported by Tomé and colleagues who use a slightly different approach involving an evaluation of the post-prandial distribution of ${ }^{15} \mathrm{~N}$ deriving from intrinsically ${ }^{15} \mathrm{~N}$-labelled proteins. This does not entirely take into account the adaptive MD but nevertheless they report overall efficiency values (NPPU) of $71-75 \%$ for pea, soya and milk protein and $66 \%$ for wheat ${ }^{(27,28)}$. In fact they report that in subjects partially adapted to a high protein intake (fed for 7 days) the increasing prior protein intake reduced the postprandial retention of wheat protein nitrogen by $10 \%$ (the NPPU fell from $61 \cdot 3$ to $55 \cdot 2 \%$ of ingested nitrogen ${ }^{(27,29)}$. This is consistent with an increased MD with the increased protein intake, which in their model would have appeared as a lower post-prandial efficiency.

These studies involving quite different methodologies demonstrate quite clearly that the efficiency of protein utilisation identified for adults in the report is incorrect and too low. This is important not only because it means that the adult MPR is overestimated but also it means that, in the factorial models for MPR values of children, in pregnancy and during lactation, the efficiency values used to derive the MPR, all of which derive from NB studies, are also too low. This is probably most important for pregnancy where an overestimation of the protein requirement may be associated with risk of weight gain and poor outcome as discussed below.

\section{Critique of values for infants and children}

The validation exercise of comparing MPR values for infants with breast milk intakes was also reinforced with experimental studies designed to clinically test the efficacy of formulations providing protein levels at or near the minimum level. Generally these studies resulted in normal growth at intakes similar to the predicted safe requirement level of new-born infants (i.e. at 1 month of age). It should be recognised that for infants, length growth is an important outcome which can be used to objectively test the adequacy of protein intakes. Thus as described in the new report ${ }^{(5)}$, some experimental studies showed that when infants were fed on formulae with protein intakes below the predicted MPR at 1 month, although weight gain and serum albumin were not affected, length gain was significantly lower. This lends confidence to the values identified by the model used for infants $<6$ months. It is the case that formulation of infant feeds must compensate for differences in dietary protein digestibility, bioavailability and efficiency of utilization between human milk and formula to meet the protein requirements of formula-fed infants. In fact the difference in the potential bioavailability of protein in breast milk and that in mixed diets was partly behind the decision to use a slightly different factorial model for infants after weaning and older children. This results in a slight increase in the MPR at 6 months

Clearly the argument above about the lack of plausibility of the low efficiency values inherent in the adult MPR is just as relevant for infants and children. In fact as discussed in the 
Table 2. Efficiency of protein utilization (PPU) measured in ${ }^{13} \mathrm{C}$-1leucine oxidation studies ${ }^{1}$

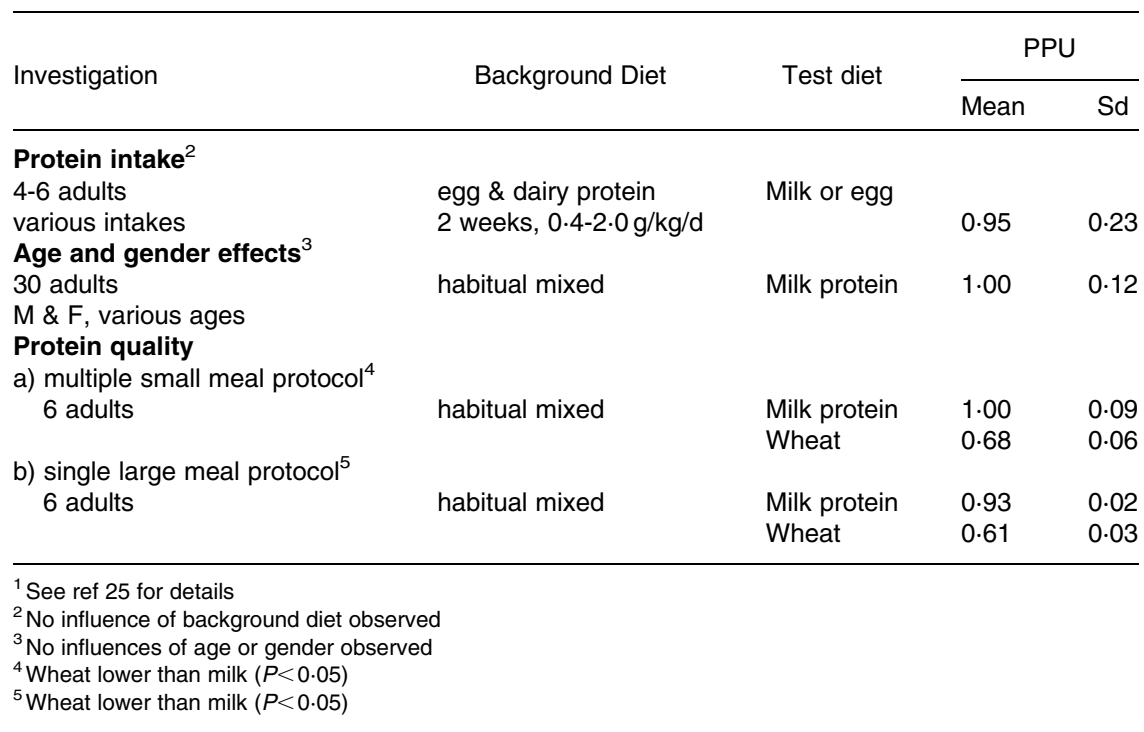

report, what information there is on preterm infants and children recovering from malnutrition suggests that although there are faecal nitrogen losses in infants $(15-23 \%$ of the intake), urinary nitrogen loss does not vary with intake, indicating an apparent biological value of milk approaching $100 \%$. This would indicate overall efficiencies of $77-85 \%$. Balance studies in growing pigs up to intakes at which growth starts to plateau indicate a slope of about $0.75^{(30)}$.

Whether any overestimation of dietary needs for maintenance and protein accretion is important needs to be considered taking account of protein's role in stimulating length growth. Such an influence certainly exists ${ }^{(31)}$ although nothing is known about its magnitude. Thus length growth may require a dietary protein intake which is greater than the MPR derived only for tissue protein maintenance and deposition during growth. Since it is not taken into account in requirement models, it might be argued that the overestimation of the requirement for growth through use of efficiency values which are too low, compensates for the lack of any specific requirement for length growth stimulation in the requirement estimate. In any case few nutritionally complete and sufficiently energy dense diets will provide intakes as low as the MPR values of young children.

\section{Critique of protein requirements for pregnancy}

There are two reasons for concern over the new values for pregnancy. Firstly as discussed in the report there are some suggestions that protein supplementation during pregnancy is associated with adverse outcomes. According to a meta analysis of randomized controlled trials aimed at reducing the incidence of small for gestational age (SGA) ${ }^{(32)}$, trials of balanced protein-energy supplementation, mainly conducted in developing countries reduced the overall risk of SGA by $30 \%,(\mathrm{RR}=0 \cdot 68,95 \% \mathrm{CI}: 0 \cdot 57-0 \cdot 80)$ although only one individual trial showed a statistically significant result. Also while there was a tendency for increased birth weight the effect was small and not significant (mean birth weight gain: $25.4 \mathrm{gm} ; 95 \% \mathrm{CI}: 23.62,54.5)$. Of three trials of isocaloric balanced protein supplementation, all showed a reduction in mean birth weight and the one trial which reported risk of SGA showed an adverse effect of supplementation. Finally a trial of high protein supplementation conducted among women of low socio economic status in the United States increased the risk of SGA and showed nonsignificant decreases in birth weight and increases in neonatal death. The authors of the meta analysis concluded that high protein supplementation during pregnancy may be harmful to the foetus and should be avoided. In the new report, to avoid this possibility the extra protein requirements for pregnancy, (and lactation), are shown together with additional energy requirements as indicated by $\mathrm{FAO}^{(33)}$. This indicates a protein:energy ratio of the extra protein and energy for the third trimester of $23 \%$. While the report states that the additional protein should be taken by consuming more of a normal diet, rather than as supplements, achieving such intakes for those populations who eat little meat may mean quite marked dietary change; in some cases a doubling of their protein intakes, and on the basis of the above discussion on risk, this may be problematic.

Secondly it is by no means a consensus view that extra energy intakes of the magnitude assumed in the report (i.e. the $\mathrm{FAO}$ recommendations of an extra $2 \mathrm{MJ} / \mathrm{d}$ in the third trimester) are safe. Many women retain extra body fat at the end of pregnancy and lactation ${ }^{(34)}$ so that pregnancy does to some extent contribute to the major public health problem of increasing body weight of women. For this reason, in the UK a lower amount of additional energy in pregnancy is recommended, namely a single daily increment of $0 \cdot 8 \mathrm{MJ} /$ day $\left(191 \mathrm{kcal} /\right.$ day) in the last trimester ${ }^{(35)}$. Thus on the basis of this recommendation for energy these additional recommended protein intakes are only achievable through isocaloric replacement throughout pregnancy since during the third trimester the extra energy and protein involves 
a P:E ratio of $65 \%$. Whether this can be achieved especially for those women at the lower end of the distribution of protein intakes, without increasing energy intakes excessively, seems to me quite doubtful.

Taken together these new values are in my view unsafe and there is an urgent case for their revision.

\section{Amino acid requirements of adults}

A re-examination of the requirements for dietary indispensable amino acids (IAA), was identified as a major part of the agenda for the recent consultation. In the 1985 report (4) the major concern had been to revise the adult protein requirement and little attention was given at that time to the values for amino acids. In fact that report included some new values for the amino acid requirements of preschool children ${ }^{(36)}$, recalculated data on older schoolboys listed in the 1973 report and values for adults which had been reported in the 1973 FAO/WHO report. These latter values were based on NB studies, many by Rose ${ }^{(37)}$ in men, and other studies in women all of which had been re-analysed by Hegsted ${ }^{(38)}$ and summarized by Irwin \& Hegsted ${ }^{(39)}$. Even though the 1973 report had stressed these adult values could be too low and had not incorporated them into a scoring pattern the 1985 report did make use of them and published age-specific IAA requirement and scoring patterns. These IAA requirement values fell markedly with age for all amino acids, from over $50 \%$ of total protein requirement in infants to only $16 \%$ in adults implying that for adults protein quality in terms of biological value was not a nutritionally important issue.

This caused concern to several involved in the issue and by the time the 1981 consultation was published in 1985 Young and colleagues had initiated new stable isotope studies to obtain better adult values which were to continue till his death in 2004. An account of the development of these studies has been described in detail elsewhere ${ }^{(40)}$. They comprised a major part of the information available to the recent consultation, and some of them are briefly examined below. Pencharz and Ball also started a major series of studies which continue today and these also contributed to the new values $^{(41)}$. These are also discussed below. The other stable isotope studies which also contributed were the ${ }^{13} \mathrm{C}$ leucine balance studies of wheat utilisation shown in Table 2, which were used to derive a value for the lysine requirement ${ }^{(42,43)}$.

All those who wrote on the subject agreed that the adult 1985 values were too low for a variety of reasons. The main problem was that in all the nitrogen balance studies no allowance had been made for miscellaneous nitrogen losses which, although small, could have a marked influence on the equilibrium value in balance curves with a shallow slope at equilibrium. Lysine was an obvious example and original balance data were re-examined by myself ${ }^{(13,44)}$ and others ${ }^{(45)}$. After correcting for the miscellaneous losses, higher values were indicated. This lead to a reanalysis of all the NB studies with revised, mainly higher adult values ${ }^{(46,13)}$. The new report considered these recalculated higher values to represent the best estimates from nitrogen balance studies.

A summary of the adult dietary indispensable amino acid requirements identified in the new report from a consideration of both the available stable isotope studies and corrected $\mathrm{N}$ balance studies is shown in Table 3 in comparison with the original and recalculated NB studies from the 1973/1985 reports. The new stable isotope values are higher for lysine (58\%), the aromatic amino acids (25\%) and especially the branched chain amino acids (11-86\%).

\section{Controversies and methodological problems with establishing amino acid requirements}

One major controversy had involved the theoretical prediction of the amino acid requirement pattern from the magnitude of the ONL and the pattern of tissue protein ${ }^{(47)}$. We ${ }^{(24)} \mathrm{had}$ suggested that during the mobilisation of tissue protein in subjects on a protein free diet, the magnitude of the tissue protein mobilised and the consequent ONL, would reflect the demand for one limiting amino acid (that with the highest ratio of demand for maintenance to its tissue protein concentration) which most likely was methionine. We listed the magnitude of the obligatory oxidative loss (OOL) for each IAA (i.e. the amino acid content of an amount of tissue protein equivalent to the ONL) and compared it with the 1985 adult IAA requirement pattern. This confirmed that methionine did have the

Table 3. Summary of the adult indispensable amino acid requirements

\begin{tabular}{|c|c|c|c|}
\hline Amino acid & 2007 report $^{1}$ mg/kg per day & 1985 report $^{2}$ mg/kg per day & Adjusted values ${ }^{3} \mathrm{mg} / \mathrm{kg}$ per day \\
\hline Histidine & 10 & $8-12$ & - \\
\hline Isoleucine & 20 & 10 & 18 \\
\hline Leucine & 39 & 14 & 26 \\
\hline Lysine & 30 & 12 & 19 \\
\hline Methionine + cysteine & 15 & 13 & 16 \\
\hline Methionine & 10 & - & - \\
\hline Cysteine & 4 & - & - \\
\hline Phenylalanine + tyrosine & 25 & 14 & 20 \\
\hline Threonine & 15 & 7 & 16 \\
\hline Tryptophan & 4 & 3.5 & 4 \\
\hline Valine & 26 & 10 & 14 \\
\hline Total indispensable amino acids & 184 & 93.5 & 143 \\
\hline
\end{tabular}


highest ratio of requirement to tissue protein content with tryptophan a close second. All other IAAs in the mobilised protein would be, by definition, released from tissue protein in excess of their demand for maintenance and would be oxidised. However Young and colleagues considered this pattern of the OOL could be the basis for the maintenance requirement pattern after its adjustment first by an increase in all values to take account of an assumed $70 \%$ efficiency of dietary utilisation to meet such losses, and then, for some amino acids, it was further adjusted with data from some early stable isotope studies. This final pattern was adopted, as the MIT requirement pattern, even though it had long been understood that the IAA pattern for maintenance was quite different to that for growth which was in effect what the MIT pattern was based on. Importantly in terms of public health policy the lysine content of the MIT IAA pattern was particularly high, not as high as the adjusted OOL value, but a value of $30 \mathrm{mg} / \mathrm{kg} / \mathrm{d}$ deriving from an early attempt to define lysine requirements by a ${ }^{13} \mathrm{C}$ tracer balance study ${ }^{(48)}$.

The theoretical and experimental basis of the MIT pattern was very controversial from the outset ${ }^{(13,46,49-51)}$ but was always vigorously defended ${ }^{(52,53)}$. In fact the critical review of the methodology of measurement of amino acid requirements in the new report concluded that predicting requirement values from the ONL and OOL could not be done apart for one limiting amino acid; such calculations were made for methionine and were used with other stable isotope data to define its requirement. In fact the persistence of Young's support for the MIT patterns is not just of academic interest. This is because, according to the way all of the $24 \mathrm{~h}$ oxidation studies are presented in the published reports, the stable isotope studies appear to have been designed to support the MIT pattern values, as discussed below.

\section{${ }^{13} \mathrm{C}$ amino acid oxidation studies}

The stable isotope studies of requirement values derive from a range of methodologies the interpretation of which are by no

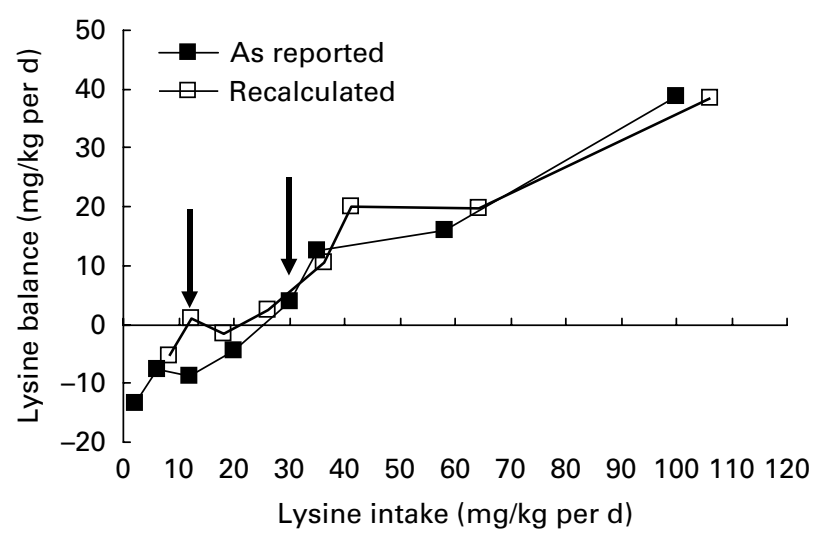

Fig. 6. ${ }^{13} \mathrm{C}$ lysine balance study used to support the MIT scoring pattern. Values for estimated $24 \mathrm{hr}$ lysine balance from measurements of ${ }^{13} \mathrm{C}$ lysine oxidation measured in the fed state in subjects fed increasing amounts of dietary lysine ${ }^{(48)}$. Filled squares are reported values while open squares are recalculated taking into account the infused tracer and an estimate of the true precursor lysine labeling (see ${ }^{13,24}$ ). means straightforward. None involve widely used standardized methods, in the way in which NB studies are employed. This made their analysis quite difficult and the new report reviewed the different approaches in some detail concluding that "the estimation of human requirements for protein and amino acids remains an inherently difficult problem" and "at present, no method is entirely reliable for determining the dietary requirement for indispensable amino acids." The ${ }^{13} \mathrm{CO}_{2}$ tracer studies in which the oxidation of a ${ }^{13} \mathrm{C}$ labelled test amino acid was used to assess the balance of the test amino acid developed by Young and colleagues were from the outset conceptually the same as NB studies: i.e. to assess the intake which allowed balance in subjects fed graded intakes of a test amino acid.

The initial ${ }^{13} \mathrm{C}$ balance studies were multilevel intake studies in the fed state of leucine, valine, lysine and threonine predicted to $24 \mathrm{hr}$ having assumed a fasted level of oxidation. There were several difficulties in conducting and interpreting these studies which were recognised by Bier et al. ${ }^{(54)}$, and examined in detail at the time ${ }^{(24,49-51)}$. The main ones were a) the need for substantial amounts of the ${ }^{13} \mathrm{C}$ "tracer," b) not knowing the precursor enrichment for ${ }^{13} \mathrm{CO}_{2}$ production, and c) the prediction of a 24 hour balance from measurements made only in the fed state. In the case of lysine ${ }^{(48)}$ the infusion rate $(0.5 \mathrm{mg} / \mathrm{kg} / \mathrm{h})$ was three times the value of the lowest level of dietary lysine intake. An example of these problems after recalculating the reported data is shown in Fig. 6 in contrast with the original reported data. Recalculation shows a zero balance (used as the proxy for the requirement), at about $15 \mathrm{mg} / \mathrm{kg} / \mathrm{d}$, half the value of $30 \mathrm{mg} / \mathrm{kg} / \mathrm{d}$ reported.

Their final methodology involved $24 \mathrm{hr}^{13} \mathrm{CO}_{2}$ tracer balance studies. However instead of using ${ }^{13} \mathrm{C}$ labelled test amino acids, the $24 \mathrm{~h}$ balance of ${ }^{13} \mathrm{C}-1$ labelled leucine is measured which can be done more reliably than for most other amino acids. With a relatively small free leucine pool its balance is assumed to be a measure of the balance of leucine in protein, i.e. a direct equivalent of $\mathrm{NB}$ in studies of subjects fed purified diets with crystalline amino acids with a pattern based on egg protein, with varying levels of test amino acids (eg phenylalanine, threonine, lysine, methionine and valine). These studies were identified as representing the state of the art but were by no means free from potential difficulties which face all such stable isotope studies as I had pointed out some years ago ${ }^{(13,44)}$.

The other large body of stable isotope studies comes from Pencharz and Ball who use the indicator amino acid oxidation (IAAO) method which is described by its authors as free from many of the problems associated with other tracer balance studies $^{(41)}$. It is important to recognise that the approach of Pencharz \& Ball is fundamentally different from that of other researchers in the field. Thus they make no attempt to discuss their measurements within any framework of amino acid requirements based on maintenance and growth stating: "Fundamentally, all of the methods used are a surrogate for measuring protein synthesis, which is hard to measure directly" (41). This is a somewhat limited view of amino acid requirements; one which would not include all components of the metabolic demand. Such an approach is unlikely to 
be able to probe amino acid requirements for non protein anabolic functions or, for example, in any of the areas of ignorance highlighted by Reeds ${ }^{(55)}$ such as intestinal amino acid metabolism. In fact this methodology derives from work used to identify the amino acid requirements for growth in livestock such as pigs and aims to identify the intake of the test amino acid which maximizes net protein synthesis and minimizes oxidation of the indicator, ${ }^{14} \mathrm{C}$ phenylalanine at a "breakpoint" in the oxidation-test amino acid intake plot. This is only very indirectly related to the overall amino acid requirement within a requirements model based on maintenance and growth. Because net protein synthesis during a meal may be less intense than in a growing animal, the demonstration of a breakpoint is in most studies quite unconvincing as shown in Fig. 7 involving two studies of the lysine requirement in children ${ }^{(56,57)}$. This is also shown for data on the lysine requirement obtained in adults during the oral infusion of tracer ${ }^{(58)}$ (Fig. 8).

In fact for both the $24 \mathrm{hr}{ }^{13} \mathrm{C}$ balance studies and the IAAO approach there is a major problem defining an end point in their studies of balance or oxidation versus intake. For the $24 \mathrm{~h}$ balance studies with each subject studied after a week or in one case 2 weeks on the test diet, the complex logistics of the studies preclude a large number of intakes and therefore most but not all studies have been underpowered in
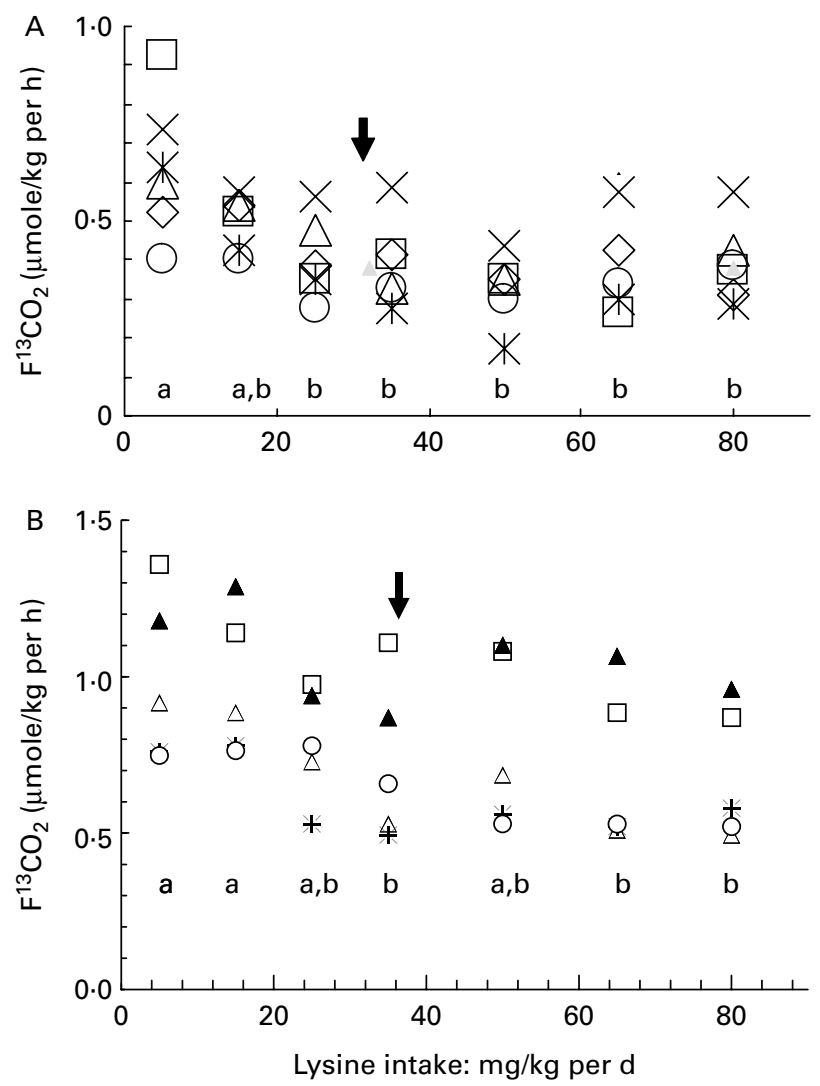

Fig. 7. Indicator oxidation studies of the lysine requirement of children Figure redrawn from values shown in Pillai et al. ${ }^{(56)}(\mathrm{A})$ and Elango et al. ${ }^{(57)}$ (B). Arrows represents the author's identification of a breakpoint in oxidation. The letters refer to homogeneous groups as assessed by post hoc testing after repeated measures ANOVA. this respect. This is particularly important in the case of lysine. It is the case that having identified a value for the lysine requirement of $30 \mathrm{mg}^{(48)}$ and incorporated it into the MIT pattern $^{(47)}$, all of the subsequent work appears from comments in the published reports to have been aimed at verifying this so that the studies with healthy Indian men ${ }^{(59)}$ were only performed with 4 or fewer intakes, e.g. $12 \mathrm{mg} / \mathrm{kg} / \mathrm{d}$ (the 1985 requirement level), $20 \mathrm{mg} / \mathrm{kg} / \mathrm{d}$ (the recalculated $\mathrm{N}$ balance value), $30 \mathrm{mg} / \mathrm{kg} / \mathrm{d}$ the expected value and one higher value $36 \mathrm{mg} / \mathrm{kg} / \mathrm{d}$. Thus none of the studies tested whether the requirement value was between 20 \& $30 \mathrm{mg} / \mathrm{kg} / \mathrm{d}$ which appears quite possible from the results reported (see Fig. 9). Only in other studies examining chronically malnourished adults was a wider range of intakes used including $25 \mathrm{mg} / \mathrm{kg} / \mathrm{d}^{(60)}$ although when these were reexamined after treatment for intestinal parasites only intakes of 30 and $45 \mathrm{mg}$ lysine were examined ${ }^{(61)}$. In other $24 \mathrm{~h}{ }^{13} \mathrm{C}-1$ leucine balance studies of phenylalanine requirements ${ }^{(62)}$ (see Fig. 10 discussed below), 8 different intakes were used so it remains a puzzle why a wider range of intakes was not used in the lysine requirement studies, arguably the most important in terms of public health policy. As it stands the $24 \mathrm{~h}{ }^{13} \mathrm{C}$ leucine balance studies show that the lysine requirement is no more than $29 \mathrm{mg} / \mathrm{kg} / \mathrm{d}$ and may be lower.

Although the design of the IAAO studies is such that more test intakes can be given it is still the case that in some key studies they are underpowered around the breakpoint. For example in studies of the lysine intake of Indian ${ }^{(56)}$ and Canadian $^{(57)}$ children shown in Fig. 7 the required endpoint, a breakpoint in ${ }^{13} \mathrm{CO}_{2}$ excretion, is very difficult to identify given the within- and between-subject variability. The authors use two phase linear regression to identify breakpoints at $33.5 \mathrm{mg}$ lysine $/ \mathrm{kg} / \mathrm{d}$ (A), and $35 \mathrm{mg} / \mathrm{kg} / \mathrm{d}$ (B). However repeated measures ANOVA reveals the change in oxidation occurs at intakes of $<25 \mathrm{mg} / \mathrm{kg} / \mathrm{d}$ in each case. More precision would require more studies at intakes intermediate between 5 and $25 \mathrm{mg} / \mathrm{kg} / \mathrm{d}$. The same criticisms can be made of most of these IAAO studies including lysine requirements of adults $^{(58,63)}$, threonine requirements in young men ${ }^{(64)}$ and of

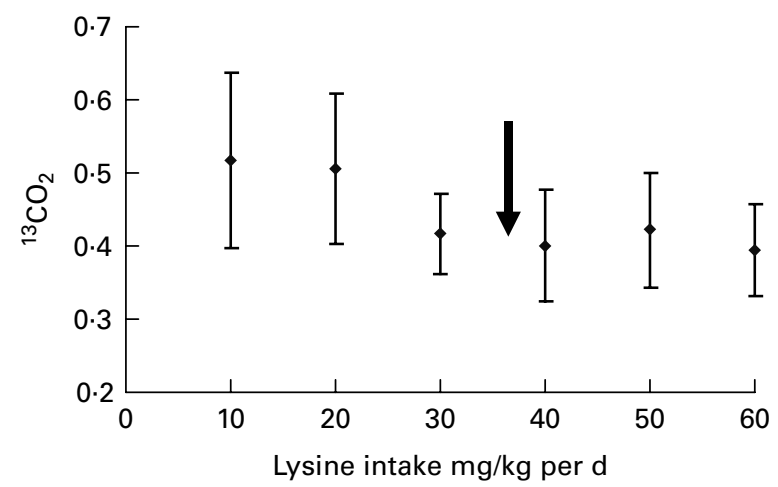

Fig. 8. Indicator oxidation studies of the lysine requirement of adults: oral tracer administration. Figure redrawn from the data of ${ }^{13} \mathrm{CO}_{2}$ excretion during an oral administration of ${ }^{13} \mathrm{CO}_{2}$ phenylalanine reported by Kriengsinyos et al. ${ }^{(58)}$. The arrow shows the breakpoint (lysine requirement) identified by the authors. 


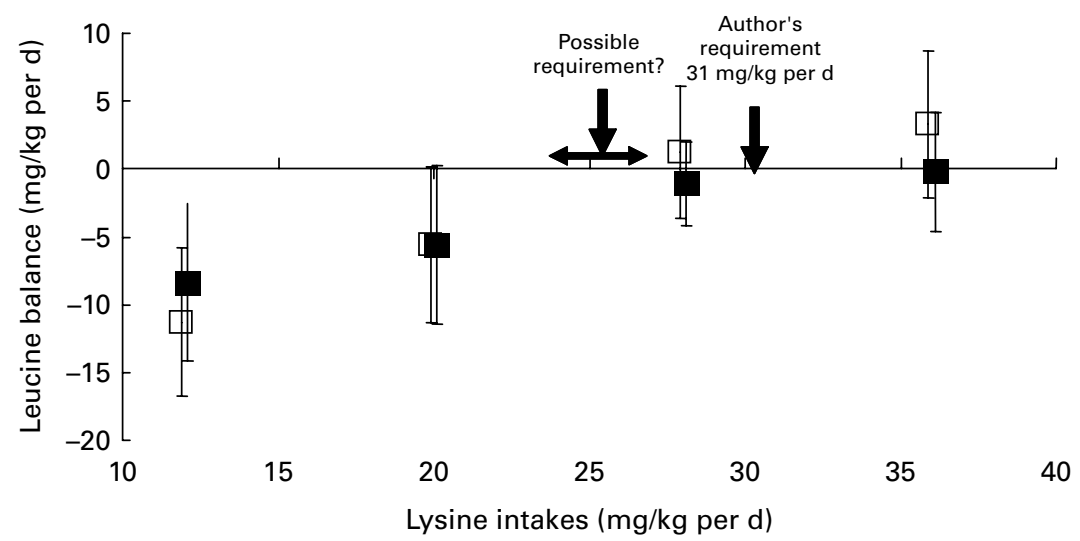

Fig. 9. $24 \mathrm{~h}$ leucine balance studies of the lysine requirement. Figure drawn from results reported by Kurpad et al. ${ }^{(59)}$. Open squares, $7 \mathrm{~d}$ of diet, closed squares $14 \mathrm{~d}$ of diet.

tryptophan requirements of young women ${ }^{(65)}$. It is the case that some statisticians and the authors of these studies argue that the two phase linear regression approach is more appropriate for identifying the overall pattern of the dose response data than ANOVA which just attempts to identify differences between individual data points. However in my view any statistical approach which identifies a break point which is not apparent from simple inspection is flawed.

In the $24 \mathrm{hr}{ }^{13} \mathrm{C}-1$ leucine balance studies the authors also use a two phase linear regression approach to identify a breakpoint (e.g. in Fig. 9). In my view the statistical validity of such an exercise with only 4 data points is even more highly questionable than the overall issue of whether a two phase regression approach involves bias when there are too few points around the breakpoint and when actual changes with intake are so small. Furthermore the SAS PROC MIXED procedure which tests whether balance points within the regression differ from zero appears to give different results compared with simple testing. This is shown in Fig. 10, i.e. $24 \mathrm{hr}{ }^{13} \mathrm{C}-1$ leucine balance studies of the requirement for the aromatic amino acids ${ }^{(62)}$. Two-phase linear regression of daily leucine balance against phenylalanine intake estimated a breakpoint in the response curve at phenylalanine intakes of $38 \mathrm{mg} / \mathrm{kg} / \mathrm{d}$, the same value predicted by Young et al. from the oxidative losses (as discussed above for lysine).
However balance was achieved at intakes of $35 \mathrm{mg} / \mathrm{kg} / \mathrm{d}$ according to testing within the regression model and at $27-31 \mathrm{mg} / \mathrm{kg} / \mathrm{d}$ according to my testing of the data as reported in the paper. A more pragmatic and transparent interpretation of these balance data as discussed above for the NB studies shown in Fig. 4 might suggest a requirement value $\approx 30 \mathrm{mg} / \mathrm{kg} / \mathrm{d}$. Finally in some of the IAAO studies reported by Pencharz \& Ball changes in plasma amino acid concentration of the test amino acid also indicate that the "requirement" is met at lower intakes than indicated by the regression model. This is shown in Fig. 11 for lysine in men ${ }^{(63)}$ and in Fig. 12 for tryptophan in women ${ }^{(65)}$. In the latter case the authors indicate that the changes in tryptophan concentrations indicate a lower "requirement" of $2 \mathrm{mg} / \mathrm{kg} / \mathrm{d}$ than that from the phenylalanine oxidation i.e. $4 \mathrm{mg} / \mathrm{kg} / \mathrm{d}$, arguing that "because the indicator amino acid technique is a direct reflection of intracellular protein synthesis, it appears likely that tryptophan availability for protein synthesis is still limited despite an increase in plasma tryptophan concentrations". My interpretation of the results is that both sets of data point to similar breakpoints at about $2 \mathrm{mg} / \mathrm{kg} / \mathrm{d}$ but the regression technique is overestimating the breakpoint through a statistical bias of the regression analysis, because the approach is underpowered around the apparent breakpoint.

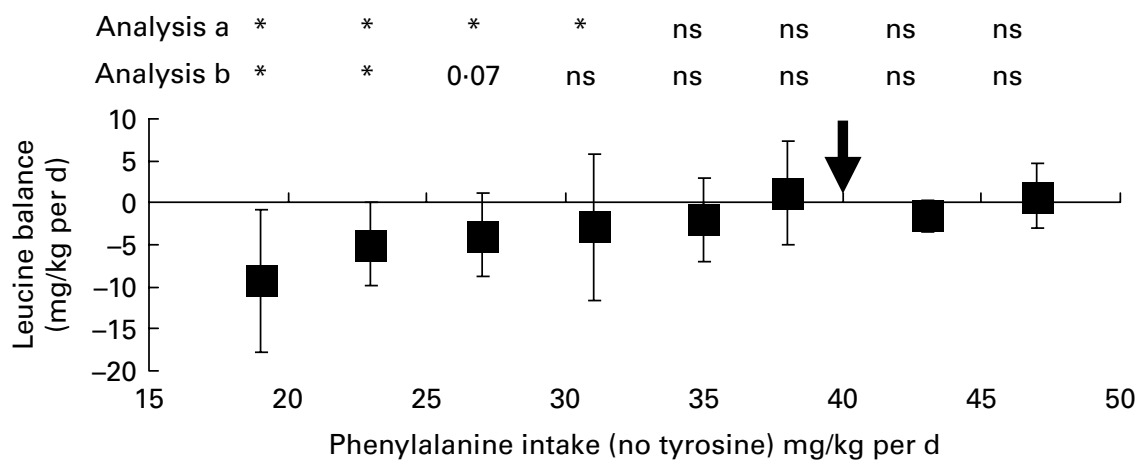

Fig. 10. 24-h ${ }^{13} \mathrm{C}-1$ leucine balance study of phenylalanine requirements ${ }^{1}$. 1. Kurpad et al. ${ }^{(62)}$. Analysis a is that reported by the authors: i.e. within regression model ( ${ }^{*}$ significantly different from zero). The breakpoint identified with two phase linear regression is at $38 \mathrm{mg} / \mathrm{kg} / \mathrm{d}$. Analysis $\mathrm{b}$ is simple testing of the difference from zero. 


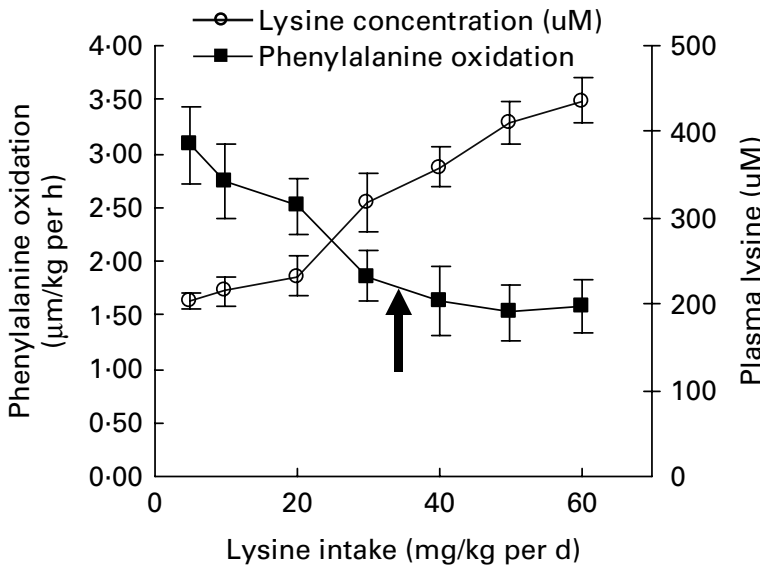

Fig. 11. Indicator oxidation studies of the lysine requirement of adults. Figure redrawn from data published by Zello et al. ${ }^{(63)}$. The arrow is the breakpoint and assumed lysine requirement $(37 \mathrm{mg} / \mathrm{kg} / \mathrm{d})$ identified by the authors whereas a value between 20 and 30 looks more appropriate.

Use of purified diets with crystalline amino acids in ${ }^{13} \mathrm{C}-1$ labelled stable isotope studies

Another issue which is seldom discussed relates to the amino acid pattern of the crystalline amino acids which is fed in these studies. In almost all cases a pattern based on egg protein is fed at $1 \mathrm{~g} / \mathrm{kg} / \mathrm{d}$. There is good evidence that the amino acid pattern of egg, which is characterised by the highest proportion of IAAs of any animal protein source ( $48 \%$ ), is limited by dietary non-essential (dispensable) nitrogen $\left(\right.$ see $\left.^{24}\right)$. This means that the requirement value obtained in these studies is unlikely to be the minimum value because the overall intake level is higher than the minimum protein level and the unbalanced IAA/NEN ratio will reduce the efficiency of utilisation of the test amino acid. How large this potential error is likely to be is difficult to predict but what is clear is that such an experimental design cannot be expected to identify the minimum IAA requirement.

\section{Amino acid requirements of infants and children}

As in the 1985 report, the new report endorsed the breast milk content and intakes of amino acids as the best estimate of amino acid requirements for infants $<6$ months of age while recognizing that such intakes may be generous compared with actual demands. The amino acid composition of mixed human-milk proteins was reported and intakes calculated from these composition values on the basis that breast milk protein intake was $75 \%$ of total nitrogen intake. For older infants and children, it was concluded at the time that no published values could be considered sufficiently secure so that a factorial approach to estimate amino acid requirements was adopted. Since the report, Pencharz \& Ball have reported more studies on children such as the values shown in Fig. 6 but it is unlikely in my view that they would have been recognised as sufficiently robust to serve as appropriate values. The factorial model was based on the maintenance and growth components of the protein requirement, and assumed the pattern of maintenance amino acid requirements for infants
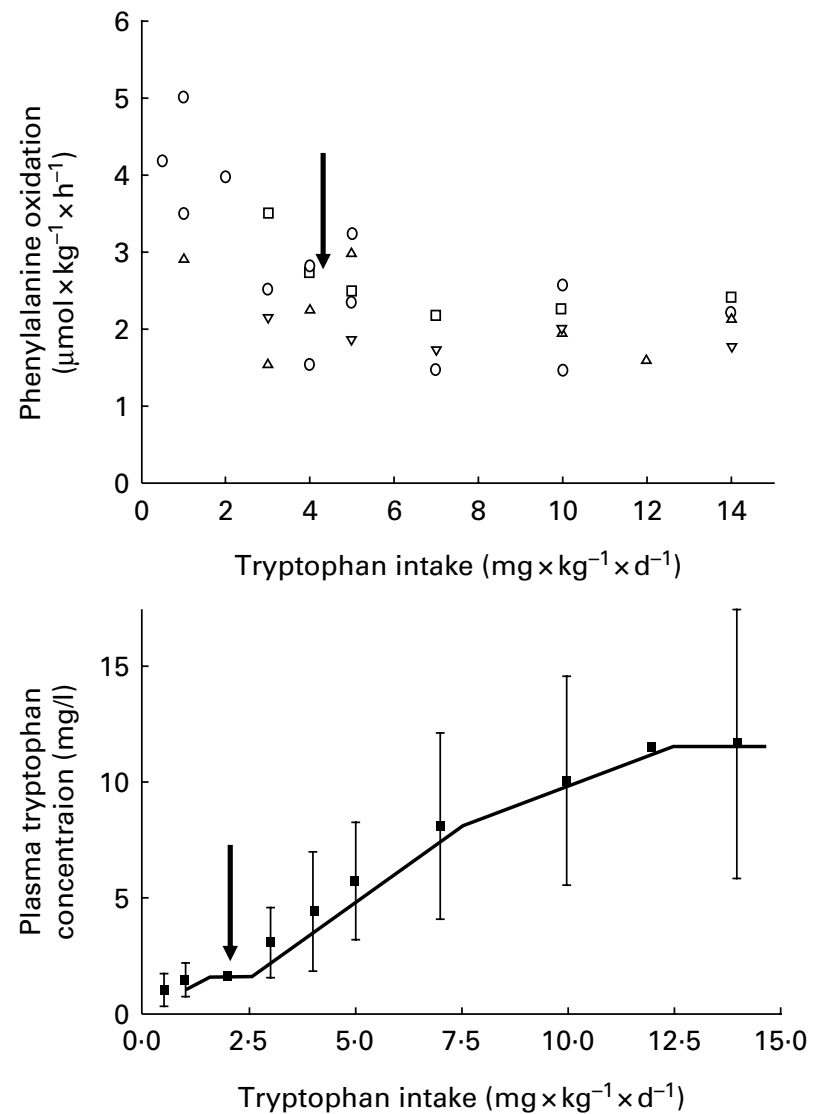

Fig. 12. Indicator oxidation studies of the tryptophan requirement of adults Figure redrawn from Lazaris-Brunner et al. ${ }^{(65)}$. The arrows represent the authors' identification of breakpoints assumed to indicate the tryptophan requirement.

and children is the same as that for adults, and the pattern of amino acid requirements for growth is given by the amino acid composition of the whole body. Thus amino acid requirements were calculated as the maintenance protein requirement $(\mathrm{g} / \mathrm{kg}$ per day) times the adult scoring pattern (mg/g protein), plus amino acids deposited during growth, i.e. the growth protein requirement times the tissue amino acid pattern, adjusted for an efficiency of deposition of 0.58 . A summary of the amino acid intakes of breast fed infants and requirement values of weaned infants, children and adults compiled from the new report is shown in Table 4 The implication of the higher IAA requirements in infants and children than adults is that the biological value of plant protein sources will be lower in infants and will rise with age. However the efficiency value used to calculate the dietary requirement for growth is low (0.58), and probably overestimates the actual value as discussed above. This means that the amino acid requirement for growth is probably overestimated and the age related fall in the overall amino acid requirements caused by the age related fall in growth is also overestimated. The implication of this is that the expected age related fall in the biological value of plant protein sources with limiting amounts of some IAA (e.g. cereals which are lysine limited) may be less than expected from the values shown in Table 4. 
Table 4. Amino acid requirements of infants children and adults

\begin{tabular}{|c|c|c|c|c|c|c|c|c|c|}
\hline Patterns: $\mathrm{mg} / \mathrm{g}$ protein & His & Ile & Leu & Lys & SAA & AAA & Thr & Trp & Val \\
\hline Breast milk & 21 & 55 & 96 & 69 & 33 & 94 & 44 & 17 & 55 \\
\hline Growth $^{1}$ & 27 & 35 & 75 & 73 & 35 & 73 & 42 & 12 & 49 \\
\hline Maintenance $^{2}$ & 15 & 30 & 59 & 45 & 22 & 38 & 23 & 6 & 39 \\
\hline Age (months) & \multicolumn{9}{|c|}{ Amino acid intakes $\left(\mathrm{mg} / \mathrm{kg}\right.$ per day) ${ }^{3}$} \\
\hline 1 & 36 & 95 & 165 & 119 & 57 & 162 & 76 & 29 & 95 \\
\hline 3 & 23 & 60 & 105 & 75 & 36 & 102 & 48 & 19 & 60 \\
\hline Age (yr) & \multicolumn{9}{|c|}{ Amino acid requirements $(\mathrm{mg} / \mathrm{kg} / \mathrm{d})^{4}$} \\
\hline 0.5 & 22 & 36 & 73 & 63 & 31 & 59 & 35 & 9 & 48 \\
\hline $1-2$ & 15 & 27 & 54 & 44 & 22 & 40 & 24 & 6 & 36 \\
\hline $3-10$ & 12 & 22 & 44 & 35 & 17 & 30 & 18 & 5 & 29 \\
\hline $11-14$ & 12 & 22 & 44 & 35 & 17 & 30 & 18 & 5 & 29 \\
\hline $15-18$ & 11 & 21 & 42 & 33 & 16 & 28 & 17 & 4 & 28 \\
\hline$>18$ & 10 & 20 & 39 & 30 & 15 & 25 & 15 & 4 & 26 \\
\hline
\end{tabular}

\footnotetext{
${ }^{1}$ Amino acid composition of whole-body protein

${ }^{2}$ Adult maintenance pattern

${ }^{3}$ Values derived from protein intakes $(75 \%$ crude protein) multiplied by the average amino acid content as $\mathrm{mg} / \mathrm{g}$ protein.

${ }^{4}$ Sum of amino acids contained in the dietary requirement for maintenance (maintenance protein $\times$ the adult scoring pattern) and growth (tissue deposition adjusted for a $58 \%$ dietary efficiency of utilization $\times$ the tissue pattern)
}

\section{Conclusions}

Most previous attempts by official committees to define protein and amino acid requirements have led to some degree of controversy and the 2007 report will be no exception. My own personal view about the overestimate of the requirements for pregnancy described above is one such issue. It is also clear from the data discussed here that the adult amino acid requirement values are likely to be overestimates. A more complicated issue is the implications of the new values for the prevalence of protein deficiency, (intake $<$ requirement), in developing and developed societies. This has been reviewed extensively elsewhere ${ }^{(66)}$ and is discussed in chapter 12 of the 2007 report and will be briefly summarised here.

The implications of the new values for protein and amino acid requirements for the adequacy of the human diet can be evaluated by comparing the safe protein:energy ratio of the requirements with what information there is on the protein quality-adjusted protein intakes in developed and developing countries. The characteristics of the P:E ratio of the requirements are to some extent counterintuitive because they are much higher for the elderly than for young children. This is because energy requirements fall with age to a greater extent than protein requirements. P:E requirement values are complicated. Values fall as physical activity increases, because of the increasing energy needs. However values increase with both increasing size, which lowers BMR and energy needs per $\mathrm{kg}$, and with female gender where BMR is lower. This means that when protein intakes are low and protein quality is poor, older large sedentary women are most at risk from protein deficiency. This population group may have a P:E requirements ratio which is twice that of very young children, requiring food with a much higher protein density ratio albeit requiring less of it per $\mathrm{kg}$ body weight.

In India average dietary intakes adjusted for protein quality on the basis of the age-related lysine scoring pattern, are judged to provide low P:E ratios which increase from 0.061 at 6 months to 0.077 for adults. For UK vegetarians comparable values rise from 0.096 to 0.102 and for UK omnivores are 0.126 for all ages. When these values are compared with the P:E ratio of the requirement for various ages and gender to estimate the prevalence of deficiency, it is clear that there is a significant risk of deficiency for some population groups in both countries. These include infants and the majority of adolescent and adult groups in India and many adult men and women UK vegetarian population groups. Even the UK omnivore diet poses a marginal risk of deficiency for large elderly sedentary woman.

One approach to this significant problem is to pursue risk management by considering the need to increase the availability of adequate supplies of high-quality protein such as legumes to those populations at risk of deficiency. This has been suggested by some ${ }^{(67)}$, on the basis that the lysine requirement has been underestimated which implies lysine intakes to be inadequate. It is the case that the new increased lysine requirement effectively reduces the available protein in the Indian diet by $13 \%$ in adults.

However in my view such risk management approaches need to take more account of the uncertainty in the requirement values. Without wanting to dismiss the possibility that there is a genuine problem, the risk assessment exercise described in the report and elsewhere ${ }^{(66)}$ must be questioned given that it not only identifies significant risk where it might be expected, but also where it would not be expected: i.e. in a UK population which would otherwise be generally considered as well nourished. The lysine requirement values are uncertain and as discussed above those values obtained in the studies which were used as the basis for the new requirement value of $30 \mathrm{mg} / \mathrm{kg}$ are likely to be an overestimate. The direct assessment of utilization of animal and plant protein sources generally fails to identify much difference (none was found in the meta analysis used by the report). Long-term nitrogen balance studies based on wheat protein or on wheat and potato protein based diets indicated body weight and fitness maintenance at lysine intakes of either $17 \mathrm{mg} / \mathrm{kg}^{(68)}$ or $24 \mathrm{mg}^{(69)}$. Given that the ${ }^{13} \mathrm{C}$-leucine balance 
studies in Fig. 9 suggest that even within this experimental situation the adult lysine requirement could be $25 \mathrm{mg} / \mathrm{kg}$ there is an urgent need for further research. If lysine needs were $25 \mathrm{mg} / \mathrm{kg}$ or lower and if the factorial model for the requirements for children used $70 \%$ rather than $58 \%$ for the efficiency for growth, then the lysine requirements of adults and most children (3-10) would be lower by $17 \%$ or more. This would allow needs to be met by some of the better cereal varieties such as QPM maize which contains $40 \mathrm{mg}$ lysine/100 g protein ${ }^{(70)}$, and which have been shown to maintain adequate growth in children ${ }^{(71)}$.

In any case the calculated deficiency risk would be different within an adaptive metabolic demand requirement framework. In this case protein intakes and requirements are correlated and the extent of between-individual variability is likely to be lower than that indicated in Fig. 2 and each of these factors would markedly reduce calculated risk of deficiency ${ }^{(72)}$. However, the incorporation of adaptation into a protein requirements model poses difficult questions in terms of risk management and the development of public health nutrition policy. In the context of providing advice on safe diets, there is little merit in departing from the current approach. Certainly caution should be exercised in any recommendation which proposes that lower intakes of foods containing protein be considered safe. Many key micronutrients and minerals accompany dietary protein so that as protein intakes fall so does dietary quality in general. Although the evidence base for an influence of protein intakes above the requirement level on health is very limited ${ }^{(73)}$, evidence for its positive influence on bone health in the elderly is growing ${ }^{(74)}$. Also height growth in children may require protein intakes above that which just provides for maintenance and protein accretion.

The report concludes its review of the implications of the new values for policy formulation, stressing the clear and urgent need for continuing research into processes and mechanisms which enable maintenance of an appropriate lean body mass and general health and wellbeing to be achieved on protein intakes as habitually consumed. It is the case that assessment of dietary adequacy in these terms is unlikely to be possible without a much better understanding of adaptive mechanisms. This and a much better understanding of the overall impact of dietary protein for long term health would enable the risk of deficiency to be defined in terms other than maintenance of $\mathrm{N}$ balance.

\section{Acknowledgements}

The author declares no conflicts of interest.

The research associated with this review received no specific grant from any funding agency in the public, commercial or not-for-profit sectors.

\section{References}

1. Food and Agriculture Organization (1957) Protein requirements Report of the FAO Committee. FAO Nutritional Studies No. 16 Rome: FAO.
2. World Health Organization/Food and Agriculture Organization (1965) Protein requirements Report of a Joint FAO/ WHO Expert Group, WHO Technical Report Series, No. 301. Geneva: WHO.

3. World Health Organization/Food and Agriculture Organization (1973) Energy and protein requirements Report of a Joint FAO/WHO ad hoc Expert Committee. WHO Technical Report Series, No. 522. Geneva: WHO.

4. World Health Organization/Food and Agriculture Organization/United Nations University (1985) Energy and protein requirements Report of a Joint FAO/WHO/UNU Expert Consultation. WHO Technical Report Series, No. 724. Geneva: WHO.

5. World Health Organization/Food and Agriculture Organization/United Nations University (2007) Protein and Amino Acid Requirements in Human Nutrition Report of a Joint WHO/FAO/UNU Expert Consultation. WHO Technical Report Series no. 935. Geneva: WHO.

6. Scrimshaw NS (1976) Shattuck Lecture: strengths and weakness of the committee approach. N Engl J Med 294, 136-142.

7. Rand WM, Pellett PL \& Young VR (2003) Meta-analysis of nitrogen balance studies for estimating protein requirements in healthy adults. Am J Clin Nutr 77, 109-127.

8. Beaton GH \& Chery A (1988) Protein requirements of infants: a re-examination of concepts and approaches. $\mathrm{Am}$ J Clin Nutr 48, 1403-1412.

9. Dewey KG, Beaton G, Fjeld C, et al. (1996) Protein requirements of infants and children. EJ Clin Nutr 50, S119-S147.

10. Badaloo A, Boyne M, Reade M, et al. (1999) Dietary protein, growth and urea kinetics in severely malnourished children and during recovery. J Nutr 129, 969-979.

11. Campbell WW, Johnson CA, McCabe GP, et al. (2008) Dietary protein requirements of younger and older adults. Am J Clin Nutr; 88, 1322-1329.

12. Millward DJ \& Roberts SB (1996) Protein requirements of older individuals. Nutr Res Rev 9, 67-87.

13. Millward DJ (1998) Metabolic Demands for Amino Acids and the Human Dietary Requirement: Millward and Rivers (1988) Revisited. J Nutr 128, 2563S-2576S.

14. Millward DJ (2001) Methodological issues. Proc Nutr Soc; 60, 3-5.

15. Millward DJ (2004) Macronutrient intakes as determinants of dietary protein and amino acid adequacy. J Nutr 134, 1588S-1596S.

16. Oddoye EA \& Margen S (1979) Nitrogen balance studies in humans: long term effect of high nitrogen intake on nitrogen accretion. J Nutr 109, 363-377.

17. Young VR, Wayler A, Garza C, et al. (1984) A long-term metabolic balance study in young men to assess the nutritional quality of an isolated soyprotein and beef proteins. Am J Clin Nutr 39, 8-15.

18. Morse MH, Haub MD, Evans WJ, et al. (2001) Protein Requirement of Elderly Women Nitrogen Balance Responses to Three Levels of Protein Intake. Gerontol A Biol Sci Med Sci 56, 11, M724-M730.

19. Campbell WW, Trappe TA, Jozsi AC, et al. (2002) Dietary protein adequacy and lower body versus whole body resistive training in older humans. J Physiol 542, 631-642.

20. Atinmo T, Mbofung CM, Hussain MA, et al. (1985) Human protein requirements: obligatory urinary and faecal nitrogen losses and the factorial estimation of protein needs of Nigerian male adults. Br J Nutr 54, 605-611.

21. Horwitt MK, Harvey CC, Rothwell WS, et al. (1956) Tryptophan-Niacin relationships in man. J Nutr 60, Suppl, 1-43.

22. Young VR, Taylor YSM, Rand WM, et al. (1973) Protein requirements of man: efficiency of egg protein utilization 
at maintenance and submaintenance levels in young men. J Nutr 103, 1164-1174.

23. Istfan N, Murry E, Janghorbani M, et al. (1983) An evaluation of the nutritional value of a soy protein concentrate in young adult men using the short-term N-balance method. $J$ Nutr 113, 2516-2523.

24. Millward DJ \& Rivers J (1988) The nutritional role of indispensible amino acids and the metabolic basis for their requirements. EJ Clin Nutr 42, 367-393.

25. Millward DJ (2003) An adaptive metabolic demand model for protein and amino acid requirements. Br J Nutr $\mathbf{9 0}$, 249-260.

26. Millward DJ \& Pacy PJ (1995) Postprandial protein utilisation and protein quality assessment in man. Clin Sci 88, 597-606.

27. Fouillet H, Bos C, Gaudichon C, et al. (2002) Approaches to quantifying protein metabolism in response to nutrient ingestion. J Nutr 132, 3208S-3218S.

28. Bos C, Juillet B, Fouillet H, et al. (2005) Postprandial metabolic utilization of wheat protein in humans. Am J Clin Nutr 81, 87-94.

29. Fouillet H, Juillet B, Gaudichon C, et al. (2009) Absorption kinetics are a key factor regulating postprandial protein metabolism in response to qualitative and quantitative variations in protein intake. Am J Physiol Regul Integr Comp Physiol 297, R1691-R1705.

30. Fuller MF \& Garthwaite O (1993) The Form of Response of Body Protein Accretion to Dietary Amino Acid Supply. J Nutr 123, 957-963.

31. Millward DJ (1995) A protein-stat mechanism for the regulation of growth and maintenance of the lean-body mass. Nutr Res Revs 8, 93-120.

32. Merialdi M, Carroli G, Villar J, et al. (2003) Nutritional interventions during pregnancy for the prevention or treatment of impaired fetal growth: an overview of randomized controlled trials. J Nutr 133, 1626S-1631S.

33. Food and Agriculture Organisiation (2004) Human energy requirements Report of a Joint FAO/WHO/UNU Expert Consultation. Food and nutrition technical report series 1 Rome, FAO.

34. Butte NF, Ellis KJ, Wong WW, et al. (2003) Composition of gestational weight gain impacts maternal fat retention and infant birth weight. Am J Obstet Gynecol; 189, 5, 1423-1432.

35. Scientific Advisory Committee on Nutrition (2011) The energy requirements of the UK population. In the press.

36. Pineda O, Torun B, Viteri FE, et al. (1981) Protein quality in relation to estimates of essential amino acid requirements. In Protein quality in humans: assessment and in vitro estimation [CE Bodwell, JS Adkins and DT Hopkins, editors]. Westport, CT, AVI, 29-42.

37. Rose WC (1957) The amino acid requirements of adult man. Nutr Abs Revs 27, 3, 631-647.

38. Hegsted DM (1963) Variation in requirements of nutrients amino acids. Fed Proc 22, 1424-1430.

39. Irwin MI \& Hegsted DM (1971) A conspectus of research on amino acid requirements of man. J Nutr 101, 539-566.

40. Millward DJ (2004) Vernon Young and the development of current knowledge in protein and amino acid nutrition: Vernon Young 1937-2004. Br J Nutr 92, 189-197.

41. Pencharz PB \& Ball RO (2003) Different approaches to define individual amino acid requirements. Annu Rev Nutr 23, $101-116$.

42. Millward DJ, Fereday A, Gibson NR, et al. (2000) Human adult protein and amino acid requirements: $\left[{ }^{13} \mathrm{C}-1\right]$ leucine balance evaluation of the efficiency of utilization and apparent requirements for wheat protein and lysine compared with milk protein in healthy adults. Am J Clin Nutr $\mathbf{7 2}$, $112-121$.

43. Millward DJ, Fereday A, Gibson NR, et al. (2002) Efficiency of utilization and apparent requirements for wheat protein and lysine determined by a single meal $\left[{ }^{13} \mathrm{C}-1\right]$ leucine balance comparison with milk protein in healthy adults. $\mathrm{Am} \mathrm{J}$ Clin Nutr 76, 1326-1334.

44. Millward DJ (1999) The nutritional value of plant based diets in relation to human amino acid and protein requirements. Proc Nutr Soc 58, 249-260.

45. Rand WM \& Young VR (1999) Statistical analysis of nitrogen balance data with reference to the lysine requirement in adults. J Nutr 129, 1920-1926.

46. Fuller MF \& Garlick PJ (1994) Human amino acid requirements: can the controversy be resolved? Ann Rev Nutr 14, 217-241.

47. Young VR, Bier DM \& Pellett PL (1989) A theoretical basis for increasing current estimates of the amino acid requirements in adult man with experimenta support. Am J Clin Nutr 50, $80-92$.

48. Meredith CN, Wen Z-M, Bier DM, et al. (1986) Lysine kinetics at graded lysine intakes in young men. Am J Clin Nutr $\mathbf{4 3}$, $787-794$.

49. Millward DJ (1990) Amino acid requirements in adult man. Am J Clin Nutr 51, 492-493.

50. Millward DJ (1994) Can we define indispensable amino acid requirements and assess protein quality in adults? J Nutr $\mathbf{1 2 4}$, 1509-1516.

51. Millward DJ (1997) Human amino acid requirements. J Nutr 127, 1842-1846.

52. Young VR \& El Khoury AE (1995) Can amino acid requirements for nutritional maintenance in adult humans be approximated from the amino acid composition of body mixed proteins? Proc Nat Acad Sci 92, 300-304.

53. McLarney MJ, Pellet PL \& Young VR (1996) Pattern of amino acids in humans: an interspecies comparison using published amino acid requirement recommendations. $J$ Nutr 126, 1871-1882.

54. Bier DM, Matthews DE \& Young VR (1985) Interpretation of amino acid kinetic studies in the context of whole-body protein metabolism. In Substrate and Energy Metabolism in Man, pp. 27-36 [JS Garrow and D Halliday, editors]. London \& Paris: John Libbey.

55. Reeds P (2001) The biology of amino acid requirements: what do they mean and can we measure them? Proc Nutr SOC 60, 13-14.

56. Pillai RJ, Elango R, Muthayya S, et al. (2010) Lysine requirement of healthy, school-aged Indian children determined by the indicator amino acid oxidation technique. J Nutr $\mathbf{1 4 0}$, 54-59.

57. Elango R, Mohammad A Humayun, et al. (2007) Lysine requirement of healthy school-age children determined by the indicator amino acid oxidation method. Am J Clin Nutr 86, 360-365.

58. Kriengsinyos W, Linda J Wykes, Ronald O Ball, et al. (2002) Oral and Intravenous Tracer Protocols of the Indicator Amino Acid Oxidation Method Provide the Same Estimate of the Lysine Requirement in Healthy Men. J Nutr $\mathbf{1 3 2}$, 2251-2257.

59. Kurpad AV, Regan MM, Raj T, et al. (2002) Lysine requirements of healthy adult Indian subjects receiving long-term feeding measured with a 24-h indicator amino acid oxidation and balance technique. Am J Clin Nutr 76, 404-412.

60. Kurpad AV, Regan MM, Raj T, et al. (2003) Lysine requirements of chronically undernourished adult Indian men, 
measured by a 24-h indicator amino acid oxidation and balance technique. Am J Clin Nutr 77, 101-108.

61. Kurpad AV, Regan MM, Nazareth D, et al. (2003) Intestinal parasites increase dietary lysine requirement in chronically undernourished adult Indian men. Am J Clin Nutr 78, $1145-1151$.

62. Kurpad AV, Meredith M, Regan, et al. (2006) The daily phenylalanine requirement of healthy Indian adults. $\mathrm{Am}$ J Clin Nutr 83, 1331-1336.

63. Zello GA, Pencharz PB \& Ball RO Dietary lysine requirement of young adult males determined by oxidation of L- $\left[1-{ }^{13} \mathrm{C}\right]$ phenylalanine Am J Physiol 264, E677-E685.

64. Wilson DC, Mahroukh Rafii, Ronald O Ball, et al. (2000) Threonine requirement of young men determined by indicator amino acid oxidation with use of L- $\left[1-{ }^{13} \mathrm{C}\right]$ phenylalanine. Am J Clin Nutr 71, 757-764.

65. Lazaris-Brunner G, Rafii M, Ball RO, et al. (1998) Tryptophan requirement in young adult women as determined by indicator amino acid oxidation with $\mathrm{L}-\left[{ }^{13} \mathrm{C}\right]$ phenylalanine. Am J Clin Nutr 68, 303-310.

66. Millward DJ \& Jackson A (2004) Protein:energy ratios of current diets in developed and developing countries compared with a safe protein:energy ratio: implications for recommended protein and amino acid intakes. Pub Health Nutr 7, 387-405.

67. Young VR, Scrimshaw NS \& Pellett PL (1998) Significance of dietary protein source in human nutrition: Animal and/or Plant Proteins? In Feeding a World Population of More than Eight Billion People: A Challenge to Science, pp. 205-221 [JC Watelow, DG Armstrong, L Fowden and $\mathrm{R}$ Riley, editors]. New York: Oxford University Press in association with Rank Prize Funds.

68. Bolourchi S, Friedmann CM \& Mickelsen O (1968) Wheat flour as a source of protein for human subjects. Am J Clin Nutr 21, 827-835.

69. Edwards CH, Booker LK, Rumph Ch, et al. (1971) Utilization of wheat by adult man: nitrogen metabolism plasma amino acids and lipids. Am J Clin Nutr 24, 181-193.

70. Ahenkora K, Twumasi-Afriyie S, Yao P, et al. (1999) Protein nutritional quality and consumer acceptability of tropical Ghanaian quality protein maize. Food Nutr Bull 20, 3, 354-360.

71. Akalu G, Taffesse S, Gunaratna N, et al. (2010) The effectiveness of quality protein maize in improving the nutritional status of young children in the Ethiopian highlands. Food Nutr Bull 31, 3, 418-430.

72. Millward DJ \& Garnett T (2010) Food and the planet: nutritional dilemmas of greenhouse gas emission reductions through reduced intakes of meat and dairy foods. Proc Nutr Soc 69, 103-118.

73. Millward DJ (1999) Optimal intakes of dietary protein. Proc Nutr Society 58, 403-413.

74. Darling AL, Millward DJ, Torgerson DT, et al. (2009) Dietary protein and bone health: a systematic review and metaanalysis. Am J Clin Nutr 90, 1674-1692. 